\title{
Aquatic Biology in Nederlo Creek, Southwestern Wisconsin
}

- तो

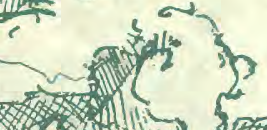<smiles>C1CCCCC1</smiles>

s.

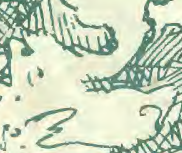

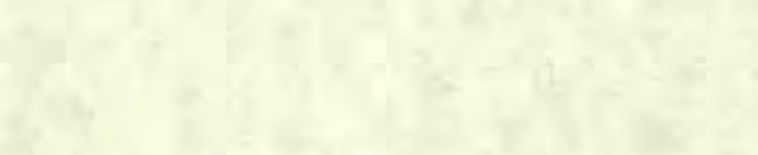

ats 12

$3 \times 2$.
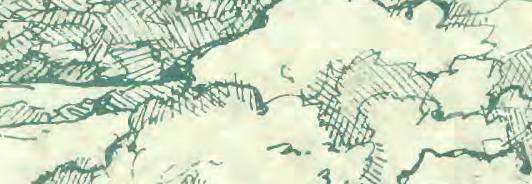

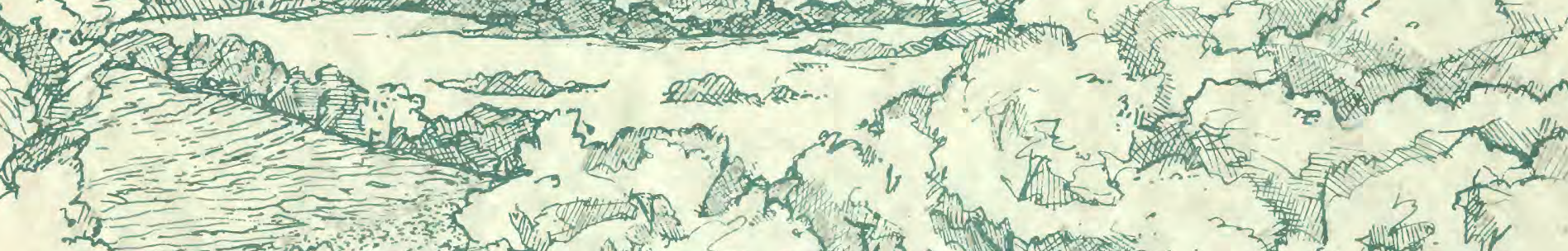
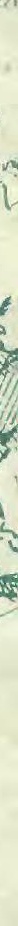

2 ate and

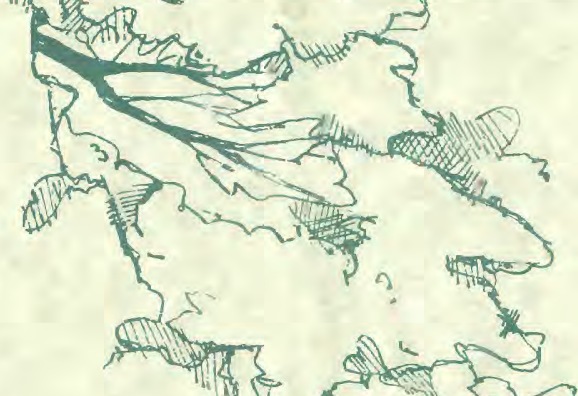

PREPARED BY

UNITED STATES DEPARTMENT OF THE INTERIOR GEOLOGICAL SURVEY

IN COOPERATION WITH

WISCONSIN DEPARTMENT OF NATURAL RESOURCES 


\section{Aquatic Biology in Nederlo Creek, Southwestern Wisconsin}

P. A. Kammerer, Jr. and R. A. Lidwin; U. S. Geological Survey

J. W. Mason and R. P. Narf; Wiscosnin Department of Natural Resources

U.S. GEOLOGICAL SURVEY

Water-Resources Investigations $\mathbf{8 2 . 5 6}$

Prepared in cooperation with

Wisconsin Department of Natural Resources

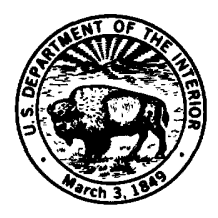

November 1982 


\title{
UNITED STATES DEPARTMENT OF THE INTERIOR
}

\author{
JAMES G. WATT, SECRETARY
}

\section{GEOLOGICAL SURVEY}

Dallas L. Peck, Director

For additional information write to:

U. S. Geological Survey

1815 University Avenue

Madison, Wisconsin 53706 


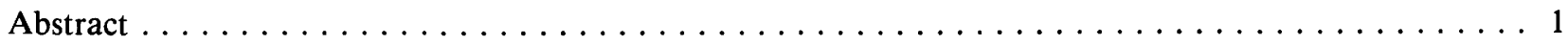

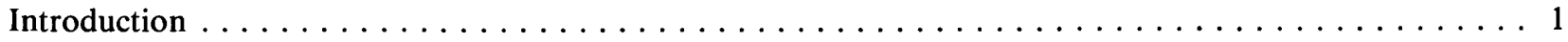

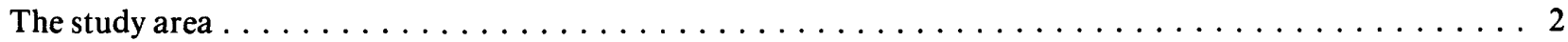

Physical setting, hydrology, and water quality $\ldots \ldots \ldots \ldots \ldots \ldots \ldots \ldots \ldots \ldots \ldots \ldots \ldots \ldots$

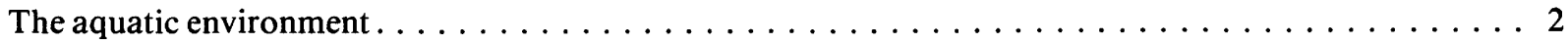

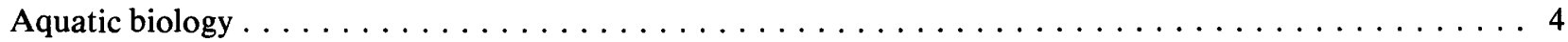

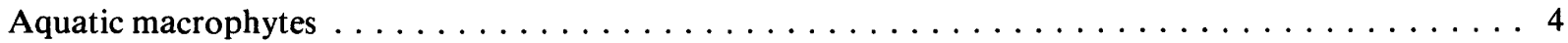

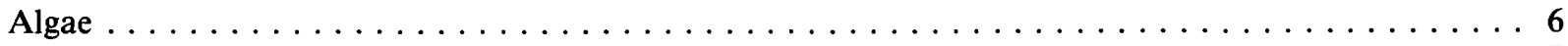

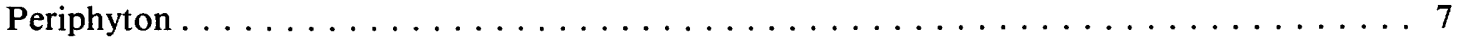

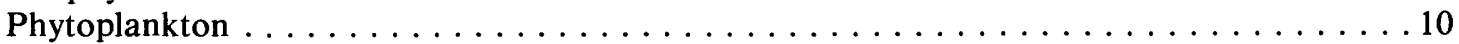

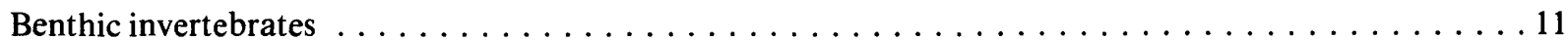

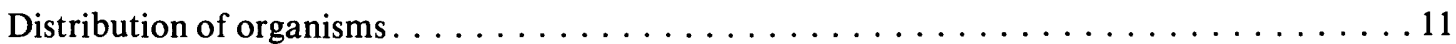

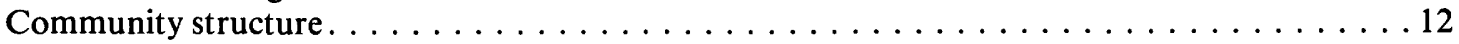

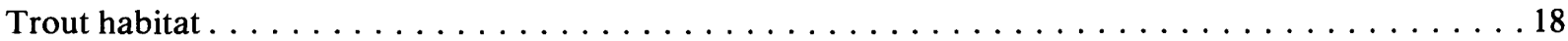

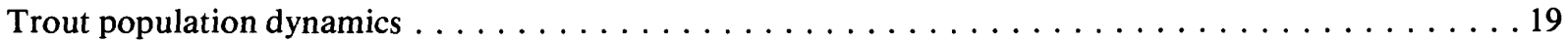

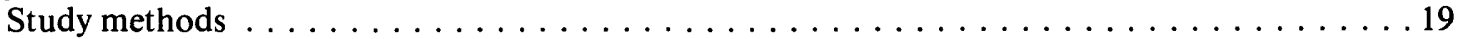

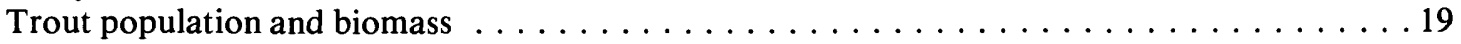

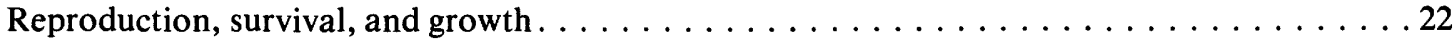

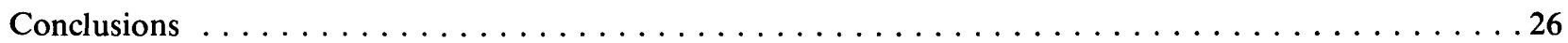

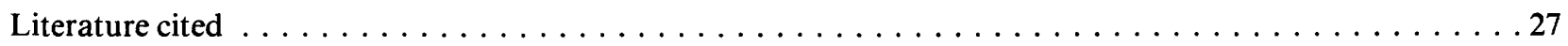

\section{ILLUSTRATIONS}

Figure 1. Map showing location of the Nederlo Creek basin in Wisconsin . . . . . . . . . 3

2. Map showing locations of biological-data collection sites $\ldots \ldots \ldots \ldots \ldots$

3. Graphs showing phytoplankton diversity, cell count, and

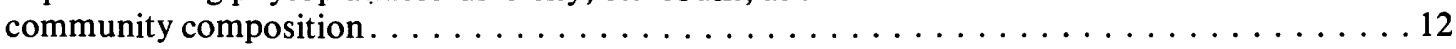

4. Histograms showing fall brown and brook trout population and biomass in Nederlo Creek . . . . . . . . . . . . . . . . . . . . . . . . . . . . 21

5. Histograms showing fall brown trout population and biomass

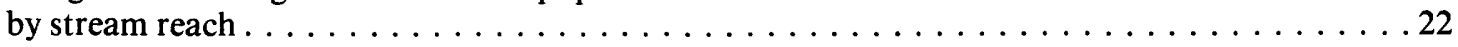

6. Map showing location of observed trout spawning sites $\ldots \ldots \ldots \ldots \ldots \ldots \ldots \ldots \ldots$

\section{TABLES}

Table 1. Distribution of aquatic macrophytes in Nederlo Creek $\ldots \ldots \ldots \ldots \ldots \ldots \ldots \ldots \ldots$

2. Periphytic algae on artificial substrates in Nederlo Creek $\ldots \ldots \ldots \ldots \ldots \ldots \ldots \ldots$

3. Summary of periphyton ash-free dry weight and chlorophyll $a$ values 


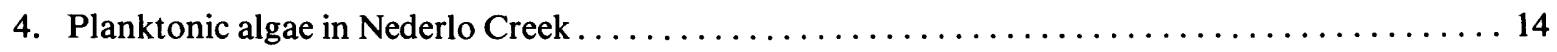

5. Characteristics of sites where benthic invertebrate samples

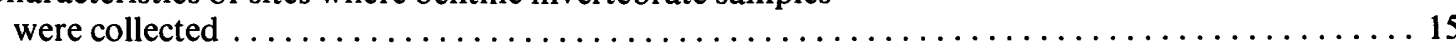

6. Distribution of benthic invertebrate species in Nederlo Creek

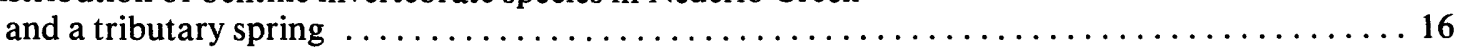

7. Biotic index values for sampling stations on Nederlo Creek $\ldots \ldots \ldots \ldots \ldots \ldots \ldots \ldots \ldots$

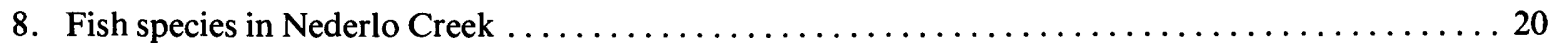

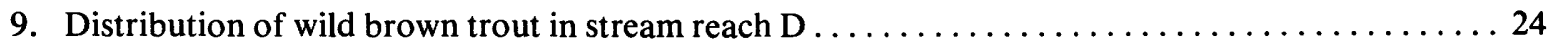

10. Fall length distribution, by age group, of wild brown trout

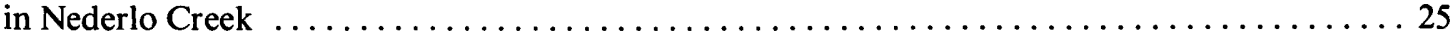

\section{CONVERSION TABLE}

For readers who prefer to use SI units rather than inch-pound units, Multiply conversion factors for terms used in this report are listed below.

in. (inch)

$\mathrm{ft}$ (foot)

mi (mile)

$\mathrm{mi}^{2}$ (square mile)

$\mathrm{ft} / \mathrm{mi}$ (foot per mile)

ton $/ \mathrm{mi}^{2}$ (ton per square mile)

$\mathrm{ft}^{3} / \mathrm{s}$ (cubic foot per second)

acre-ft (acre-foot)

$\mathrm{lb}$ (pound)
By

To obtain

25.40

0.3048

1.609

2.590

0.1894

0.3503

$2.832 \times 10^{-2}$

$1.233 \times 10^{3}$

0.454 mm (millimeter)

m (meter)

km (kilometer)

$\mathrm{km}^{2}$

$\mathrm{m} / \mathrm{km}$ (meter per kilometer)

$\mathrm{t} / \mathrm{km}^{2}$ (metric ton per square kilometer)

$\mathrm{m}^{3}$ (cubic meter per second)

$\mathrm{m}^{3}$ (cubic meter)

kg (kilogram) 


\title{
Aquatic Biology in Nederlo Creek, Southwestern Wisconsin
}

\author{
P. A. Kammerer, Jr. and R. A. Lidwin; U. S. Geological Survey
}

J. W. Mason and R. P. Narf; Wiscosnin Department of Natural Resources

\begin{abstract}
This report presents the results of biologic investigations by the U.S. Geological Survey and the Wisconsin Department of Natural Resources during a study of hydrology and water quality in a small drainage basin in the "Driftless Area" of southwest Wisconsin. The investigation included aquatic macrophytes, periphytic and planktonic algae, benthic invertebrates, and trout population dynamics during 1967-78.

The aquatic community is diverse and reasonably stable with little indication of environmental disturbance. Aquatic macrophyte population (dominated by Ranunculus aquatilis L., Veronica catenata Penn., and Nasturtium officinale) varies little from spring to fall. Periphytic and planktonic algae are predominantly diatoms, with the genus Achnanthes dominating both communities. Most genera of planktonic algae originate in the periphyton, but some true planktonic algae were identified. The benthic invertebrate population is dominated by Trichoptera and is a major food source for trout and forage fish. Biotic index values calculated from benthic invertebrate data indicate that water quality is very good to excellent. The trout population is low and represents only a small part of the total fish population both in biomass and numbers. Brown trout are usually stocked annually in the spring to enhance sport fishing, but by fall most trout are wild. The major environmental factors limiting trout population seem to be insufficient cover, insufficient pool depth and volume, and small spawning areas. The wild trout population is highly dependent on spawning success the previous fall.
\end{abstract}

\section{INTRODUCTION}

A cooperative study of the Nederlo Creek basin by the U.S. Geological Survey (USGS) and the Wisconsin Department of Natural Resources (DNR) began in 1967 to determine the effects of a small reservoir and a dry floodwater-control structure on hydrology and water quality. In 1968, Federal research funds were obtained by the USGS for more detailed water-quality studies and to extend the scope of the project to include aquatic biota and the aquatic environment.

Concurrent studies of fish and benthic invertebrates in Nederlo Creek were made by the DNR. These studies all began before construction of the structures and were to continue beyond completion of construction. Results of the preconstruction phase of the USGS-DNR cooperative project have been published (Kammerer and Sherrill, 1979).

The two water-retention structures originally planned were part of a comprehensive watershed protection, flood prevention, and recreation plan for the Blackhawk-Kickapoo watershed (Crawford and Vernon County Soil and Water Conservation Districts, 1967). Construction of the dry floodwatercontrol structure began in July 1974 and was completed in November 1975. Plans for construction of the second structure have been cancelled, leading to changes in the objectives and scope of this investigation.

The completed structure is not expected to have a significant effect on downstream water quality and biota. Because of this and the change in construction 
plans, the planned postconstruction investigation of the effects of the structures on Nederlo Creek was not made. The results of the preconstruction biologic studies, which were to be published in the report covering the postconstruction investigation, are contained in this report.

The purpose of this report is to present the results of the preconstruction biologic investigations by the USGS and DNR. The report is intended to complement and add to the scope of the material in the previously published report (Kammerer and Sherrill, 1979).

\section{THE STUDY AREA}

\section{Physical Setting, Hydrology, and Water Quality}

Characteristics of the study area, including geography, geology, soils, land use, hydrology, water quality, and stream-channel characteristics were described in detail by Kammerer and Sherrill (1979). These characteristics are summarized here to provide background information on the terrestrial and aquatic environment.

The study area includes the surface drainage basin of Nederlo Creek (locally used name, not approved by the U.S. Board on Geographic Names). The basin is $4 \mathrm{mi}$ northwest of Gays Mills (Crawford County) in the "Driftless Area" of southwestern Wisconsin (fig. 1), has a surface drainage area of $11.0 \mathrm{mi}^{2}$, and is geographically and hydrologically similar to other small basins in the area. Topography is rugged, with approximately $400 \mathrm{ft}$ of relief between the ridgetops that form the surface drainage divides and the floor of the valley that contains the perennial reaches of Nederlo Creek and its tributaries.

The bedrock that forms the ridges and underlies Johnstown Valley is sandstone and dolomite of Cambrian and Ordovician age. In the valley, the bedrock is overlain by unconsolidated alluvium of Pleistocene and Holocene age. The alluvial material is as thick as $20 \mathrm{ft}$ at the sites of the structures (fig. 1) and thickens toward the mouth of the valley.

Soils may be divided into groups or associations based on texture and parent material. Silty upland soils are predominant on the ridgetops, but small areas of sandy, silty soils are also present. Valley walls are stony colluvial land, which is actually a mixture of soil material and rocks. Most of the soils in the valley are silty alluvial soils, but sandy, silty soils underlie smaller areas.

Land is used primarily for agriculture and farm woodlots. Fifty percent of the land is cropland and 40 percent is woodland; of the remaining 10 percent, 7 percent is permanent pasture and 3 percent is occupied by roads and buildings.

The stream is characterized by fairly constant base flow and rapid changes in discharge during periods of snowmelt or rain. Surface runoff is a significant contributor to streamflow only 10 percent of the time; during the remaining 90 percent of the time, streamflow consists entirely of ground-water runoff, most of which can be attributed to discharge from springs.

Water in the stream at base flow is a calcium magnesium bicarbonate type, having a median hardness of $286 \mathrm{mg} / \mathrm{L}$ (milligrams per liter) as calcium carbonate and median dissolved-solids concentration of $274 \mathrm{mg} / \mathrm{L}$. Dissolved-oxygen concentrations in the streams are generally lowest during summer, when lows of $7-8 \mathrm{mg} / \mathrm{L}$ are common at night.

The daily fluctuation of stream temperature is greatest in the summer; the range and the magnitude of daily extreme values at specific locations are influenced by the proximity of springs. Maximum daily water temperatures as high as $26^{\circ} \mathrm{C}$ have been measured at some locations, but temperatures this high seldom persist for more than a few hours. Water temperatures during winter (December through February) usually range from $0^{\circ}$ to $5^{\circ} \mathrm{C}$.

Mean annual suspended-sediment loads at various locations ranged from 13 to 60 tons $/ \mathrm{mi}^{2}$; most of the sediment ( 74 to 86 percent) is transported during that 10 percent of the time when overland flow contributes to streamflow.

\section{The Aquatic Environment}

Physical characteristics of the stream channel itself (slope, mean width and depth, streambankerosion rates, and bed material particle size) were described by Kammerer and Sherrill (1979).

Livestock management practices have substantial influence on the aquatic environment, especially with respect to trout habitat. Cattle had continuous 


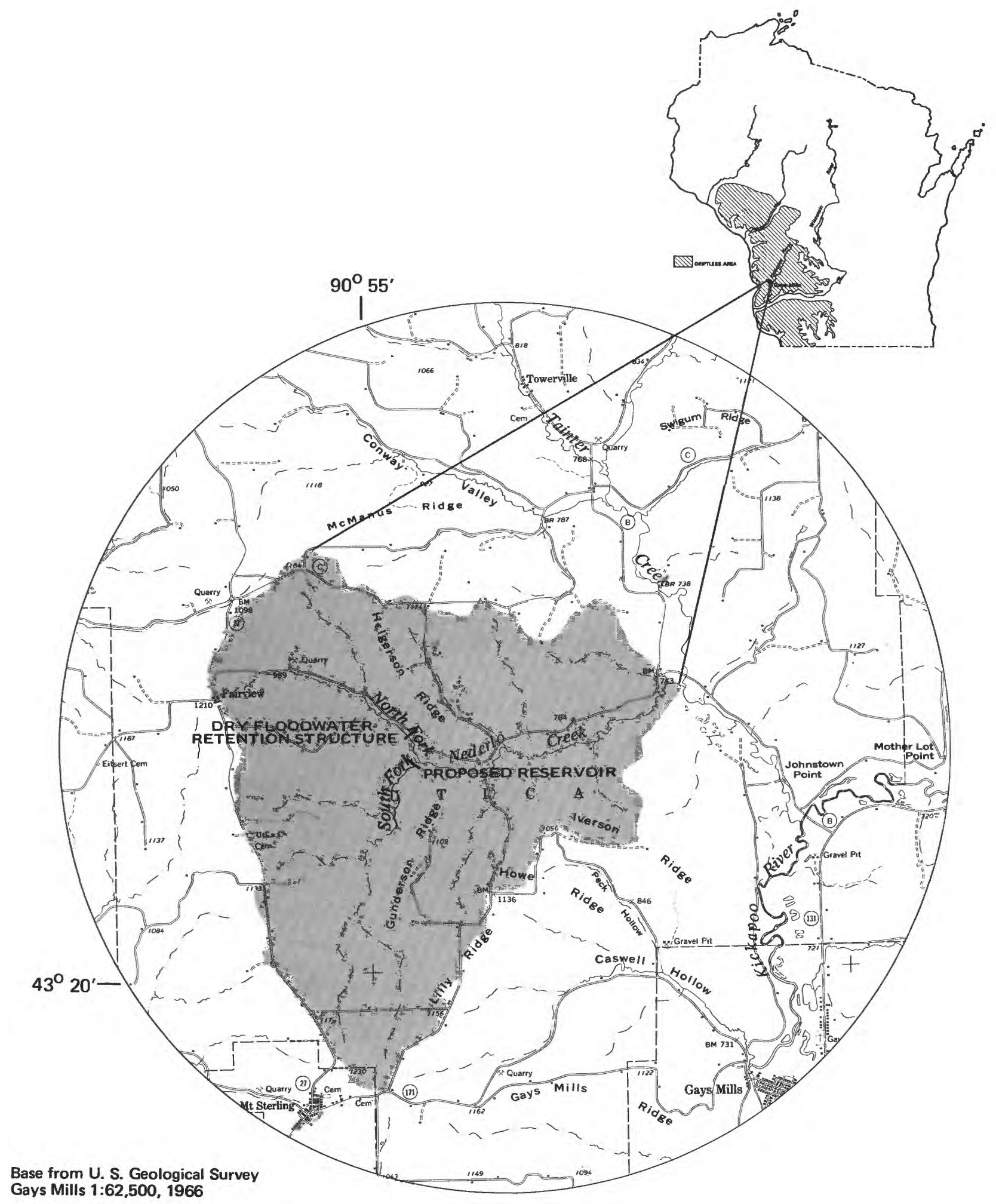

Figure 1. Location of the Nederlo Creek basin in Wisconsin. 
access to almost the entire length of Nederlo Creek and its tributaries during the period of study. In the short reaches where access was not continuous, cattle grazed during at least part of the study.

The most visible effect of grazing was to limit the quantity of cover for trout and other aquatic organisms that would normally be provided by overhanging streambank vegetation. In stream reaches where grazing was intermittent, streambank vegetation approached "natural" conditions during years of no grazing; high grass on the banks hung over the water, and fast-growing shrubs (primarily willow) shaded the stream from direct sunlight during most of the day. When these reaches were grazed, grass was close cropped, and the shrubs were destroyed. Streambanks grazed each year were generally free of larger vegetation (shrubs and trees), and grass, where present, was short and provided little cover.

\section{AQUATIC BIOLOGY}

Aquatic organisms studied include macrophytes, periphytic and planktonic algae, benthic invertebrates, and trout and forage fish. Characteristics of these populations and their relation to one another and the aquatic environment are discussed in later sections.

\section{Aquatic Macrophytes}

The distribution of aquatic macrophytes was recorded twice annually from August 1970 to June 1977 at 19 bench-mark stream cross sections downstream from the two proposed structures; locations of the cross sections are shown in table 1. Visits were made in spring (late May or early June) and fall (late September or early October).

Three species of aquatic macrophytes are predominant in Nederlo Creek--Ranunculus aquatilis L. (water buttercup), Veronica catenata Penn. (water speedwell), and Nasturtium officinale $\mathrm{R}$. Br. (watercress). The relative abundance of these species at each site (as measured by the percentage of the streambed inhabited) and areal variation in their distribution may be seen in the data summaries in table 1.

Ranunculus is the most abundant of the three genera. It is widely distributed along the main stem of Nederlo Creek and in the south fork, but absent in the north fork. The percentage of the streambed at each cross section inhabited by Ranunculus varied considerably over the study, but no seasonal trends were apparent. The average percentage of streambed inhabited by Ranunculus was similar for spring and fall measurements.

Veronica is usually less abundant than Ranunculus, but the areal distribution of the two genera is similar. Mixed beds of Veronica and Ranunculus grow at many of the cross sections. Veronica grows at the mouth of the north fork (section 16) but not at any of the upstream sections. As with Ranunculus, seasonal trends in the abundance of Veronica are not apparent; abundances for spring and fall measurements are similar.

Nasturtium has been observed at all but one of the sections, but it is most abundant at the sections on the north fork. The abundance of Nasturtium is much less than that of Ranunculus and Veronica on the south fork and at stations on the main stem of Nederlo Creek. The greatest abundance of Nasturti$u m$ in the north fork is probably due, at least in part, to the influence of nearby springs on water temperature (Kammerer and Sherrill, 1979); Nasturtium is common in and near springs where summer water temperatures are generally lower than in stream sections farther from the springs. The average abundance of Nasturtium was greater in fall than in spring at all the sections.

Nasturtium provides cover and protection for fingerling trout and cover for benthic invertebrates. Its importance in this regard is increased by the scarcity of other suitable cover in the stream and on the streambanks.

The summaries in table 1 show that the range of abundance for each genus (as represented by the range of percentage values) is large at most sections. Usually, each genus was absent at least once at each section even where average percentage values are high. The absence of one or more genera at a section sometimes seemed to be due to mechanical removal (erosion) caused by high streamflow before the site visit. The effects of a particular occurrence of high streamflow differed from section to section, but stream discharges covering the range discussed by Kammerer and Sherrill (1979) did not cause widespread damage to or destruction of aquatic macrophytes during the monitoring (August 1970-June 1977). 
Table 1. Distribution of aquatic macrophytes in Nederlo Creek.

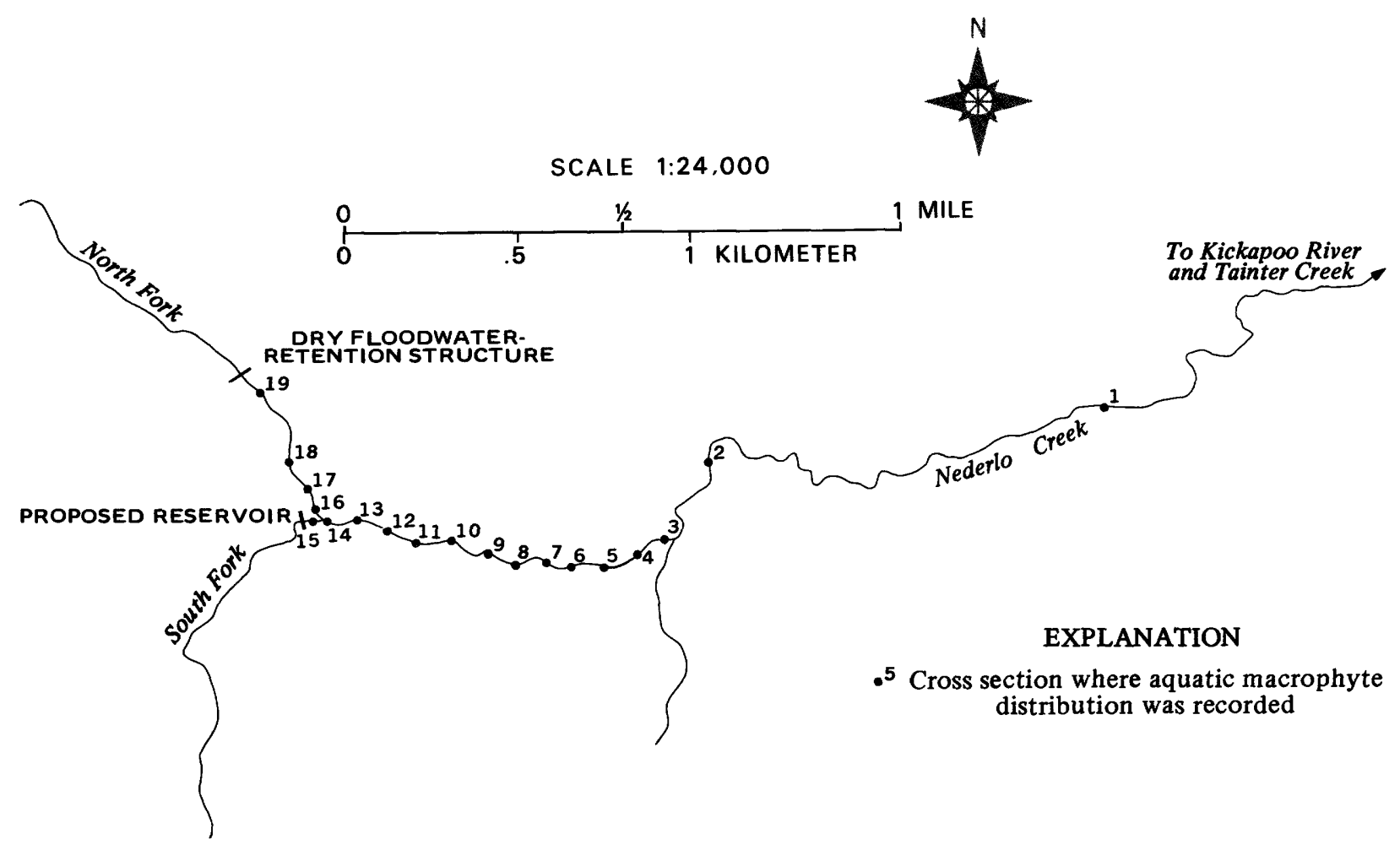

PERCENTAGE OF STREAMBED INHABITATED BY AQUATIC MACROPHYTES, AUGUST 1970 - JUNE 1977*

\begin{tabular}{|c|rc|rc|cc|}
\hline CROSS & \multicolumn{2}{|c|}{ Ranunculus } & \multicolumn{2}{c|}{ Veronica } & \multicolumn{2}{c|}{ Nasturtium } \\
SECTION & MEAN & RANGE & MEAN & RANGE & MEAN & RANGE \\
\hline Nederlo Creek & & & & & & \\
1 & 7 & $0-34$ & 0 & 0 & 0 & 0 \\
2 & 21 & $0-54$ & 0 & $0-1$ & .1 & $0-1$ \\
3 & 28 & $1-66$ & 2 & $1-12$ & .5 & $0-1$ \\
4 & 44 & $1-84$ & 1 & $0-13$ & .5 & $0-1$ \\
5 & 6 & $0-71$ & 3 & $0-30$ & 1.2 & $0-6$ \\
6 & 40 & $4-66$ & 29 & $1-83$ & 3.0 & $0-25$ \\
7 & 29 & $0-68$ & 6 & $0-20$ & 5.2 & $0-33$ \\
8 & 32 & $0-62$ & 22 & $1-57$ & 9.0 & $0-54$ \\
9 & 13 & $0-30$ & 11 & $0-50$ & 2.4 & $0-12$ \\
10 & 10 & $0-31$ & 9 & $0-25$ & .9 & $0-7$ \\
11 & 17 & $0-66$ & 6 & $0-26$ & 1.9 & $0-26$ \\
12 & 14 & $0-35$ & 23 & $1-47$ & 3.0 & $0-35$ \\
13 & 11 & $0-38$ & 29 & $1-54$ & 8.8 & $0-38$ \\
14 & 0 & $0-1$ & 3 & $0-13$ & .5 & $0-1$ \\
South Fork & & & & & & \\
15 & 39 & $0-86$ & 12 & $1-35$ & 5.0 & $0-28$ \\
North Fork & & & & & & \\
16 & 0 & 0 & 7 & $0-32$ & 2.5 & $0-87$ \\
17 & 0 & 0 & 0 & 0 & 47 & $0-100$ \\
18 & 0 & 0 & 0 & 0 & 22 & $0-65$ \\
19 & 0 & 0 & 0 & 0 & 28 & $0-75$ \\
\hline
\end{tabular}

*14 measurements at each site 
Destruction of aquatic macrophytes was widespread during the record floods on June 17 and June 30-July 1, 1978. The June 17 flood, which had a probable recurrence interval of 40-50 years, resulted from 5.10 in. of rain on saturated soil during a 20-hour period. The June 30-July 1 flood, which had a probable recurrence interval exceeding 100 years, resulted from 6.8 in. of rain in a 12-hour period. These floods were the maximum floods of record at gaging stations in and near the study area. An inspection in September 1978 revealed that the flood had removed all visible aquatic macrophytes from the entire length of Nederlo Creek and its tributaries.

\section{Algae}

Phytoplanktonic (free-floating) algae and attached algae in the periphyton community are useful in assessing the biological quality or trophic status of a stream. In small streams, the algal component of the periphyton community is particularly useful in this assessment. Periphyton and phytoplankton samples were collected approximately monthly between May 1974 and November 1977 at four sites (fig. 2). These sites include two on the main stem of Nederlo Creek (stations 70 and 90) and one each on the north and south forks (stations 30 and 60, respectively). Periphyton samples were also collected periodically during $1968-71$, but these data were used primarily to check the long-term consistency of the 1974-77 data, which are emphasized in this report.

Methods used in collection, identification, and enumeration of algae and for chlorophyll and biomass determinations are described by Greeson and others (1977). Periphyton samples were collected by anchoring polyethylene strips on the stream bottom for 4-6 weeks (average time 35 days) to allow colonization by periphytic organisms. Phytoplankton samples were collected by submerging a polyethylene bottle near the centroid of streamflow and allowing it to fill with water. Algae were identified to the genus level.

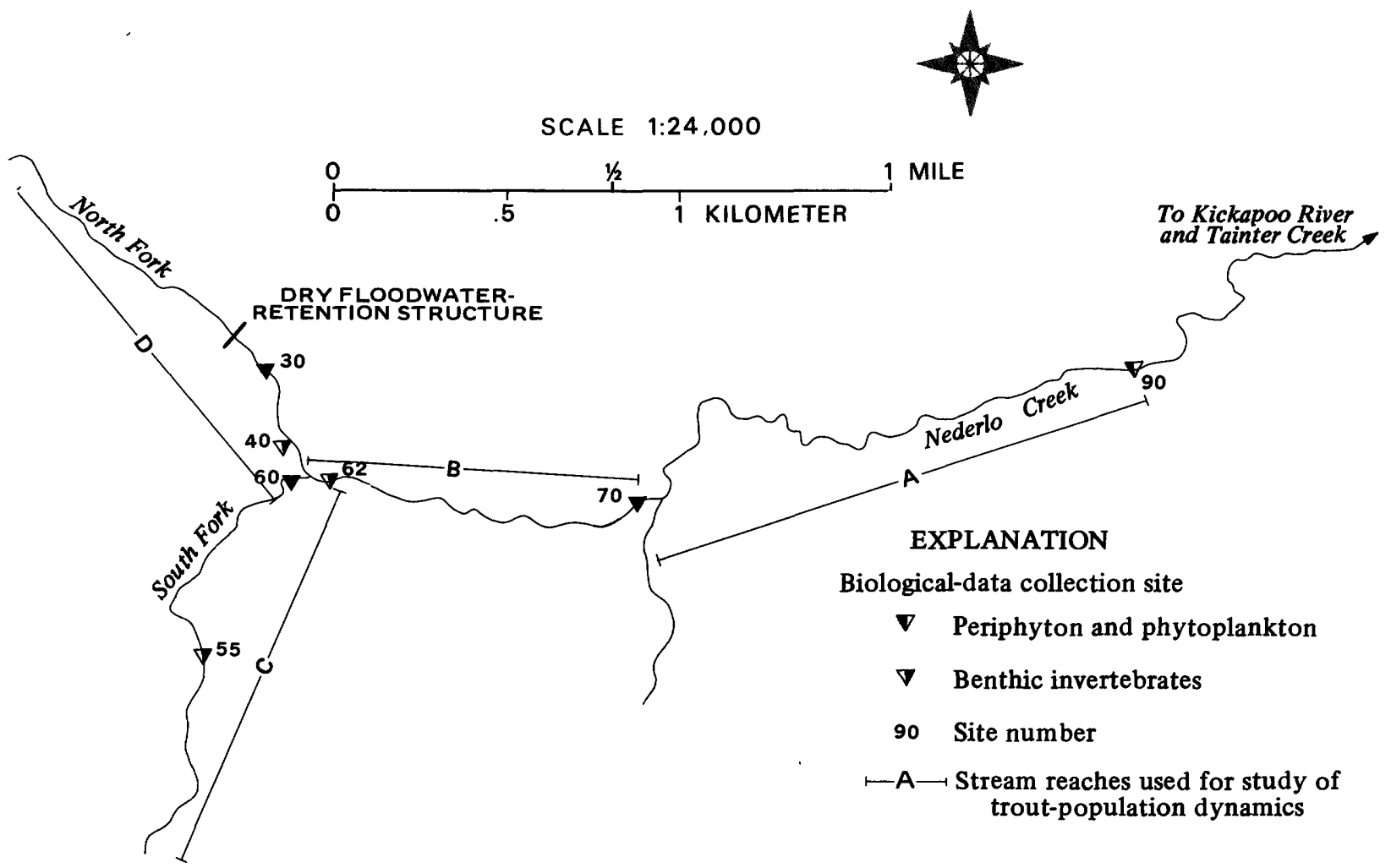

Figure 2. Location of biological-data collection sites. 


\section{Periphyton}

Diatoms are the dominant periphytic algae at all four sampling sites. The frequency of occurrence of the algal genera found in the periphyton samples is given in table 2 . It can be seen from the data in the table that the generic composition of the periphytic algae is similar at all four sampling sites.

A seasonal succession of dominant genera takes place in the stream. The diatoms Achnanthes, Gomphonema, and Navicula are generally dominant during the winter. In the summer, the blue-green algae Oscillatoria and Lyngbya become increasingly important. The green algae Stigeoclonium and Ulothrix are abundant during most of the year and at times constitute a considerable part of the periphytic algae.

The use of artificial substrates may influence the species composition of the periphyton samples. Filamentous blue-green algae, for example, prefer a stable substrate, and it is unlikely that they would colonize the artificial substrates to the extent that they might be found on more solid substrates such as rocks.

Maximum diatom populations (as indicated by biomass and chlorophyll measurements) generally occur in the spring and fall. This pattern corresponds to that generally observed in streams of temperate regions (Whitton, 1975). The pattern in Nederlo Creek is masked somewhat by the yearround dominance of the diatoms Achnanthes, Gomphonema, Navicula, and Nitzschia. This tends to obscure the apparent increases in population of other diatom genera.

Chlorophyll $a$ and ash-free dry weight (AFDW) measurements were made on the periphyton samples to identify temporal and areal variation of biomass production in the periphyton community. Ash-free dry weight is a composite measure of all organic material (biomass) produced in the periphyton community, and chlorophyll $a$ is a measure of biomass production by the algal component of the periphyton. Hypotheses concerning temporal and areal variation of these variables were tested statistically. Mean AFDW and chlorophyll $a$ values for the four sampling sites and for various seasonal groupings of data were compared by an $\mathrm{F}$ test at $\mathrm{P}=0.05 ; \log$ transformation of the data was necessary to meet the requirements of the test.
The $\mathrm{F}$ test showed no significant difference $(\mathrm{P}=$ 0.05 ) between the mean AFDW values from the four sampling sites. Testing of mean chlorophyll $a$ values for the four sites showed that the mean values for sites 60,70 , and 90 (fig. 2) were not significantly different from each other, but that the mean value for station 30 (fig. 2) was significantly lower than the means for the other stations. This is an indication that algal biomass produced in the periphyton community was lower at station 30 than at the other stations.

Ash-free dry weight and chlorophyll $a$ findings are summarized in table 3. Ash-free dry-weight data for the four sites are combined, based on the results of the F test. Chlorophyll $a$ data for stations 60,70 , and 90 were also combined, but the values for station 30 are summarized separately.

The AFDW and chlorophyll $a$ data were also examined for seasonal trends. Based on the previous analysis of areal variation, AFDW data for all stations were combined, and the chlorophyll $a$ data were divided into two groups--the combined data for stations 60, 70, and 90 and the data for station 30. To test for seasonal differences, the data were divided into groups based on the month in which the samples were collected. Two subdivisions of the year were made: the first by dividing the year into four periods ("quarters") and the second by dividing it into three periods ("thirds"). The months included in each of these groups are shown below.

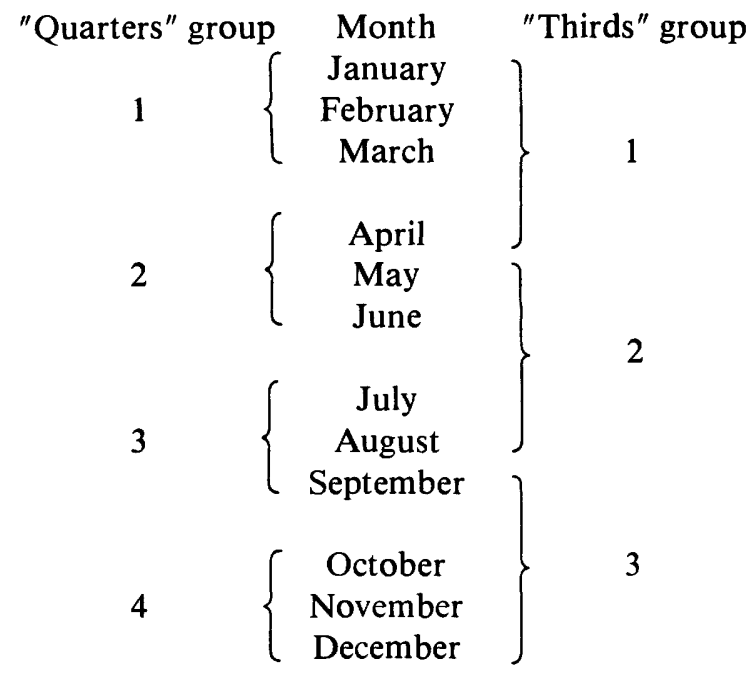

Mean AFDW and chlorophyll $a$ values for the data within each division were compared by the $F$ test described previously; the test showed no significant difference $(P=0.05)$ in the mean values between "quarters" or between "thirds". 
Table 2. Periphytic algae on artificial substrates in Nederlo Creek.

\begin{tabular}{|c|c|c|c|c|}
\hline \multirow{3}{*}{$\begin{array}{l}\text { Order } \\
\quad \text { Pamily } \\
\quad \text { Genus }\end{array}$} & \multicolumn{4}{|c|}{$\begin{array}{l}\text { Percentage of samples in which } \\
\text { genus was present }\end{array}$} \\
\hline & \multicolumn{4}{|c|}{ Station (see fig. 2) } \\
\hline & 30 & 60 & 70 & 90 \\
\hline \multicolumn{5}{|l|}{$\begin{array}{l}\text { Chlorophyta } \\
\text { Chlorophyceae (Green algae) }\end{array}$} \\
\hline 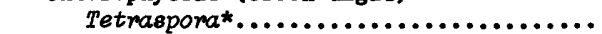 & - & 3 & -- & - \\
\hline ulothrix...................... & 38 & 76 & 45 & 37 \\
\hline Stigsoctonium................. & 81 & 74 & 76 & 66 \\
\hline Coleochaete*.................. & - & 3 & - & - \\
\hline Gongrosira*................... & - & 3 & 9 & 3 \\
\hline Cladophora*..................... & - & -- & 9 & 9 \\
\hline Oedogonium...................... & 22 & 62 & 33 & 57 \\
\hline Characium* $, \ldots, \ldots, \ldots, \ldots, \ldots, \ldots, \ldots, \ldots$ & 12 & 6 & -- & - \\
\hline Scenedesmuв.................... & - & 9 & 9 & 3 \\
\hline 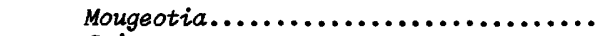 & - & 6 & -- & - \\
\hline spirogyra..................... & 3 & 3 & - & 9 \\
\hline Closterium......................... & 3 & 3 & 3 & 3 \\
\hline Cosmarium*......................... & - & 3 & 3 & 3 \\
\hline \multicolumn{5}{|l|}{ Buglenophyta } \\
\hline Euglenophyceae (Euglenolds) & & & & \\
\hline 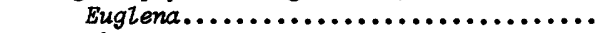 & - & 6 & -- & 11 \\
\hline 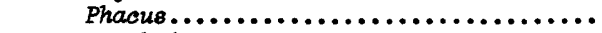 & - & -- & -- & 3 \\
\hline Trachelomonas....................... & - & - & - & 3 \\
\hline \multicolumn{5}{|l|}{ Chrysophyta } \\
\hline Xanthophyceae (Yellow-green algae) & & & & \\
\hline 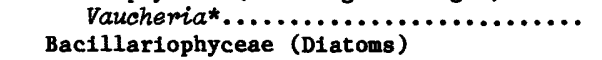 & 3 & 6 & 3 & - \\
\hline 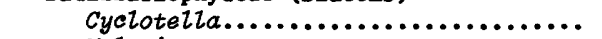 & 6 & 18 & 6 & 3 \\
\hline Melosira.......................... & 19 & 65 & 48 & 46 \\
\hline Meridian........................... & 38 & 38 & 48 & 29 \\
\hline 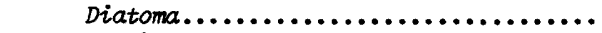 & - & 26 & 52 & 74 \\
\hline opephora............................ & -- & 3 & 3 & - \\
\hline 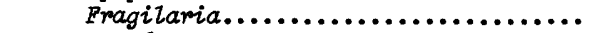 & 22 & 44 & 45 & 43 \\
\hline synedra............................ & 75 & 65 & 85 & 89 \\
\hline Hannaea*.$\ldots \ldots \ldots \ldots \ldots \ldots \ldots \ldots \ldots$ & - & -- & 3 & - \\
\hline Eunotia $, \ldots, \ldots, \ldots, \ldots, \ldots, \ldots, \ldots, \ldots$ & 3 & -- & - & 3 \\
\hline Achnanthes $\ldots \ldots \ldots \ldots \ldots \ldots \ldots \ldots \ldots$ & 97 & 94 & 97 & 97 \\
\hline Cocconeis........................... & 91 & 97 & 97 & 86 \\
\hline Rhoichosphenia..................... & 19 & 59 & $2 i$ & 17 \\
\hline 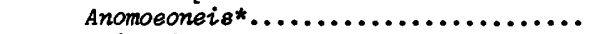 & - & -- & - & 3 \\
\hline Caloneis............................. & 9 & 15 & 6 & 6 \\
\hline Gyrosigma........................... & 6 & 3 & - & 3 \\
\hline 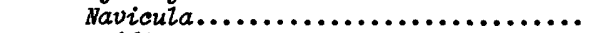 & 94 & 100 & 100 & 100 \\
\hline Neidium.......................... & -- & 3 & 3 & 9 \\
\hline Pinnularia........................ & 6 & 32 & 12 & 14 \\
\hline Stauroneis........................... & 3 & 3 & 3 & 9 \\
\hline 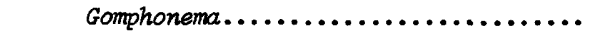 & 97 & 97 & 100 & 97 \\
\hline 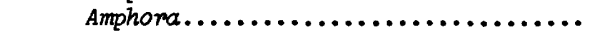 & 3 & 24 & 3 & 9 \\
\hline 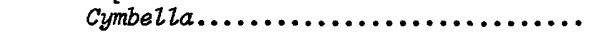 & 62 & 97 & 97 & 97 \\
\hline Epithemia............................ & -- & - & - & 3 \\
\hline Denticula*.......................... & -- & 3 & 3 & - \\
\hline 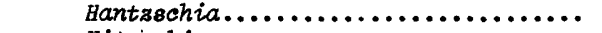 & -- & -- & -- & 11 \\
\hline Nitzschia $\ldots \ldots \ldots \ldots \ldots \ldots \ldots \ldots \ldots \ldots$ & 81 & 97 & 100 & 100 \\
\hline Cymatopleura......................... & 19 & 41 & 70 & 89 \\
\hline 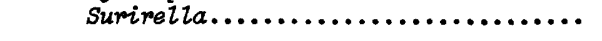 & 53 & 68 & 79 & 86 \\
\hline \multicolumn{5}{|l|}{ Cyanophyta } \\
\hline Myxophyceae (Blue-green algae) & & & & \\
\hline Anacystis.......................... & - & - & - & 3 \\
\hline Agmenellum......................... & 25 & 29 & 18 & 9 \\
\hline Entophysalis* $\ldots \ldots \ldots \ldots \ldots \ldots \ldots \ldots \ldots$ & 19 & 3 & 3 & - \\
\hline Lyngbya........................... & 53 & 68 & 64 & 57 \\
\hline 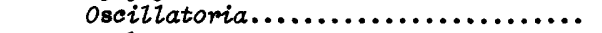 & 59 & 65 & 73 & 71 \\
\hline Anabaena...$\ldots \ldots \ldots \ldots \ldots \ldots \ldots \ldots$ & -- & - & 3 & -- \\
\hline 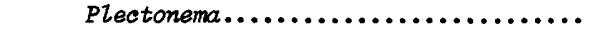 & 12 & -- & 6 & 9 \\
\hline \multicolumn{5}{|l|}{$\begin{array}{l}\text { Rhodophyta } \\
\text { Rhodophyceae (Red algae) }\end{array}$} \\
\hline Audouinella*..................... & -- & - & 6 & -- \\
\hline
\end{tabular}

*Genus present in periphyton but not in phytoplankton. 
Table 3. Summary of periphyton ash-free dry weight and chlorophyll a values.

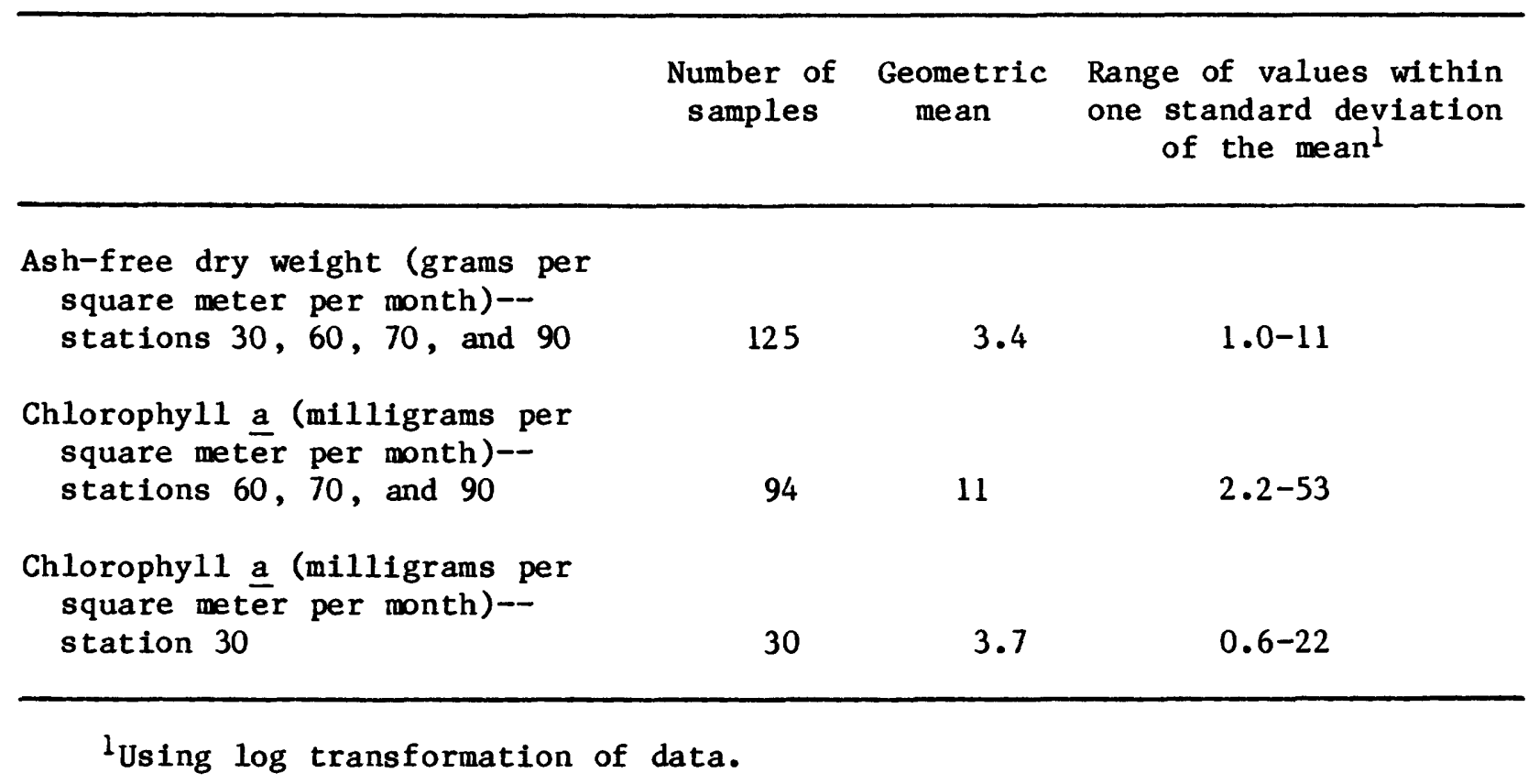

Two other seasonal combinations of data were tested to compare AFDW and chlorophyll $a$ values for "warm" and "cold" seasons. In the first combination tested, data from quarters 2 and 3 were combined to represent "warm" months, and data from quarters 1 and 4 were combined to represent "cold" months. The F test showed no significant difference $(P=0.05)$ in the mean AFDW or chlorophyll $a$ values between the "warm" and "cold" periods.

The second combination used data from thirds 1 and 3 to represent "cold" months and data from third 2 to represent "warm" months. In this case, the $F$ test revealed a significant difference $(P=0.05)$ in mean AFDW between periods; the mean AFDW for the "warm" period is $4.4\left(\mathrm{~g} / \mathrm{m}^{2}\right) /$ month , which is almost twice the mean value of $2.8\left(\mathrm{~g} / \mathrm{m}^{2}\right) /$ month for the "cold" period. The test showed no significant difference in mean chlorophyll $a$ values between the "warm" and "cold" periods.

The higher mean AFDW value for third 2 (representing May, June, July, and August) indicates that the warmer temperatures favor increased biomass production in the heterotrophic segment of the periphyton community. Seasonal trends may also occur in chlorophyll $a$ values, but, if they do occur, they are masked by large month-to-month variation in chlorophyll $a$ production.
The ratio of AFDW to chlorophyll $a$ has been used as an index of the relative organic enrichment or trophic state of streams. Weber (1973) refers to this ratio as the autotrophic index (AI) and reports a range of index values of 50-100 as normal for biologically stable streams (those not showing biological effects of organic enrichment). Organic enrichment favors growth of the heterotrophic organisms in the periphyton, especially saprobic organisms such as bacteria and fungi. Preferential growth of these organisms causes increases in AFDW relative to chlorophyll $a$ and, consequently, higher AI.

AI values calculated from AFDW and chlorophyll $a$ data from the four sampling stations had a wide range. Examination of the AI values showed that values for 1977 were considerably higher than those for 1974-76. The highest for 1974-76 was 4,000 , but approximately 20 percent of the 1977 values exceeded 10,000 . A shift in AI of this magnitude would normally indicate a drastic disturbance in the aquatic environment, but no such disturbance was indicated by other organisms and biological indicators (phytoplankton diversity, composition of the benthic invertebrate community) used in the study. The shift in 1977 AI values was apparently due to a change in the analytical procedure for chlorophyll $a$, which produced lower values; the lower chlorophyll $a$ values caused the apparent increase in AI. Because of this, 1977 AI values were not included in the following analysis. 
One-way analysis of variance was used to test for differences in AI between stations. An F test at $\mathbf{P}=$ 0.05 using $\log$ transformed AI values showed no significant difference between mean AI for stations $30,60,70$, and 90 . Based on the results of this test, AI values for all stations were combined and summarized for the basin as a whole. The summary includes 23-25 values per station for a total of 95 .

AI for 1974-76 ranged from 22 to 4,000; the median of 211 agrees closely with the mean of 230 derived from the log-transformed AI values. Fiftypercent of the AI values fall between the 25th quartile value of 108 and the 75th quartile value of 394; values in this range are taken as typical of Nederlo Creek and its tributaries.

This range is higher than the range of $50-100$ given by Weber (1973) as normal for biologically stable streams, but the higher values do not seem to be due to any readily identifiable biological disturbance or water-quality problem. This conclusion is supported by other biological data presented in subsequent sections of this report. It is more likely that the range of values given by Weber is not applicable to southwestern Wisconsin streams.

\section{Phytoplankton}

The phytoplankton in Nederlo Creek is dominated by diatoms, but green and blue-green algae are also present. About two-thirds of the 61 algal genera represented in the phytoplankton are periphytic and originate as dislodged cells through abrasion by suspended material in the stream and other means (Blum, 1956; Whitton, 1975). Overall, the diatom Achnanthes is the dominant genus the periphyton and the phytoplankton. The frequency of occurrence of algal genera in phytoplankton samples is given in table 4.

Twenty-one algal genera (table 4) were found exclusively in phytoplankton samples--of these, only two are known to have periphytic forms. This is an indication that populations of euplankton (true planktonic algae) exist in Nederlo Creek. These genera were identified in less than 20 percent of the phytoplankton samples and were present in small numbers. Other genera such as Synedra, Diatoma, Scenedesmus, and Melosira are planktonic but were also found in periphyton samples. These planktonic algae may originate in stagnant water and pools within and tributary to the stream.
Seasonal changes occur in the population of planktonic algae (as indicated by cell counts) and in the relative numbers of diatoms and green and blue-green algae. The histograms and graphs in figure 3 illustrate the changes at stations $30,60,70$, and 90 (fig. 2). The general dominance of diatoms is shown in the histograms, but blue-green algae (primarily Oscillatoria) predominated on several occasions, particularly in 1976 and 1977 and especially at station 30. Green algae, when present, were a minor component of the phytoplankton. Cell counts followed normal seasonal trends (Whitton, 1975), with counts generally highest in the summer at all four stations.

A diversity index was used to evaluate the composition of the phytoplankton. The diversity index ( $\bar{d})$ values were computed for each phytoplankton sample by the formula of Wilhm and Dorris (1968). High values of $\bar{d}$ (greater than 3 ) indicate a diverse population not dominated by a small number of taxa; populations of this sort generally occur in relatively undisturbed, "healthy" environments. Low values of $\bar{d}$ (less than 1) indicate a less diverse population dominated by a small number of taxa, which is generally characteristic of disturbed or stressed environment.

Values of $\bar{d}$ plotted on figure 3 are reasonably constant, and, with few exceptions, seasonal trends are not apparent. Low or decreasing $\bar{d}$ values at stations 30,60, and 70 during the summer of 1977 seem to coincide with the increase in population of blue-green algae during this period. Low $\bar{d}$ values were also apparent during the summers of 1975 and 1976 at station 90 . This station, being the farthest from headwater springs, may be more susceptible to biological stresses imposed by farming practices, such as allowing livestock in the stream, than the upstream stations. The influence of farming practices on water quality would be expected to be greatest in the summer.

Values of $\bar{d}$, generally between 2 and 3 , indicate that the phytoplankton is not affected by any major environmental stress. The relative constancy of $\bar{d}$ with time indicates that seasonal increases and decreases in the total phytoplankton population are probably due to changes in the populations of most of the genera present rather than to large increases or decreases in a few dominant genera. 


\section{Benthic Invertebrates}

Collections of benthic invertebrates were made with a Surber sampler $\left(1 \mathrm{ft}^{2}\right)$ at five sites on Nederlo Creek and its tributaries between October 1968 and October 1978. Locations of the sampling sites (stations $70,62,60,55$, and 30 ) are shown on figure 2. Collections were made from riffles at each site, but substrate and flow conditions (morphometry) differed from site to site. A brief summary of the physical characteristics of each sampling site is given in table 5 along with approximate dimensions of the pool upstream from the collection site.

Invertebrates were collected 11 times during the study. The collections were made in spring, fall, and winter (7 in March, 3 in October, and 1 in January) to avoid the fluctuating populations characteristic of summer. The organisms were preserved in 95-percent ethanol.

\section{Distribution of Organisms}

Sixty-one taxa were represented in samples collected from the five stream-sampling sites, of which 16 taxa were predominant. A list of the organisms and the sites at which they were collected are given in table 6. Predominant organisms are marked with an asterisk. The order Trichoptera (caddisflies) was the most frequently represented group. Chironomidae collected before 1971 are not included in the data summarized in table 6 due to the poor larval taxonomic keys available when samples were analyzed; this omission includes 5 of the 11 dates for which collections were made.

Differences were noted in the site-to-site distribution of several of the taxa. The differences are probably a result of site morphometry (habitat) preferences of various taxa rather than site-to-site variations in water quality.

Site 70 (fig. 2), the site farthest downstream, differed from the others primarily in the distribution of Trichoptera (caddisflies). Hydropsyche cf. betteni and Symphitopsyche cf. bifidia were found almost exclusively at this site, and S. sparna was present in greater numbers than at other sites. In contrast, Brachycentrus americanus was less abundant at this site than at other locations. The dipterian Antocha sp. was also more abundant at this site.

Site 62, (fig. 2) is upstream from site 70 , just downstream from the confluence of the two forks of
Nederlo Creek. This site differs from the others in that it seldom receives direct sunlight. The distinguishing feature of the benthic invertebrate population at site 62 was the greater abundance of the Ephemeroptera (mayfly) Stenonema fuscum .

At site 60, which is near the mouth of south Fork Nederlo Creek, populations of the caddisfly Symphitopsyche slossonae and the Coleoptera (beetle) Optioservus fastiditus (adults and larvae) and Helichus striatus were generally greater than those at the other sites (fig. 2). The caddisfly Symphitopsyche sparna, which was abundant at site 70 , was not found at site 60 .

Site 55 (fig. 2) is near the headwaters of south fork Nederlo Creek. The case-bearing caddisfly Hesperophylax designatus was found almost exclusively at this site. The organisms were typically clumped on the downstream sides of large rocks generally not found at other sites, so the presence of this substrate was an important factor influencing their occurrence. The Plecoptera (stonefly) Isoperla signata was present in smaller numbers here than at other sites. The caddisfly Brachycentrus americanus was not found at this site during the first part of the study, but small populations were found in later samples.

Site 30 (fig. 2) is about $200 \mathrm{ft}$ downstream from the floodwater-retention structure on north fork Nederlo Creek. The mayfly Stenonema fuscum was generally more abundant here than at other sites. As at site 55, the caddisfly Brachycentrus americanus was not found before 1970. Populations of this organism in samples collected in 1970 and succeeding years were similar to those found at sites 60 and 62 and generally greater than at sites 70 and 55 .

Little seasonal variation in species composition was noted in the samples. An exception to this is the mayfly Baetis brunneicolor, which was found mainly in October samples. The lack of seasonal variation is probably due in part to the moderating influence of springs on water temperatures in the stream, especially in the spring and fall.

Collections of invertebrates were made in the large spring (site 40 , fig. 2) tributary to north fork Nederlo Creek in March 1977 and in March and October of 1978. Substrates found in the spring included coarse sand and gravel, a few stones, and leaf mats. Species found in the spring are listed in table 6. Seven of the 21 species identified were found exclusively in the spring. The similarity in aquatic 

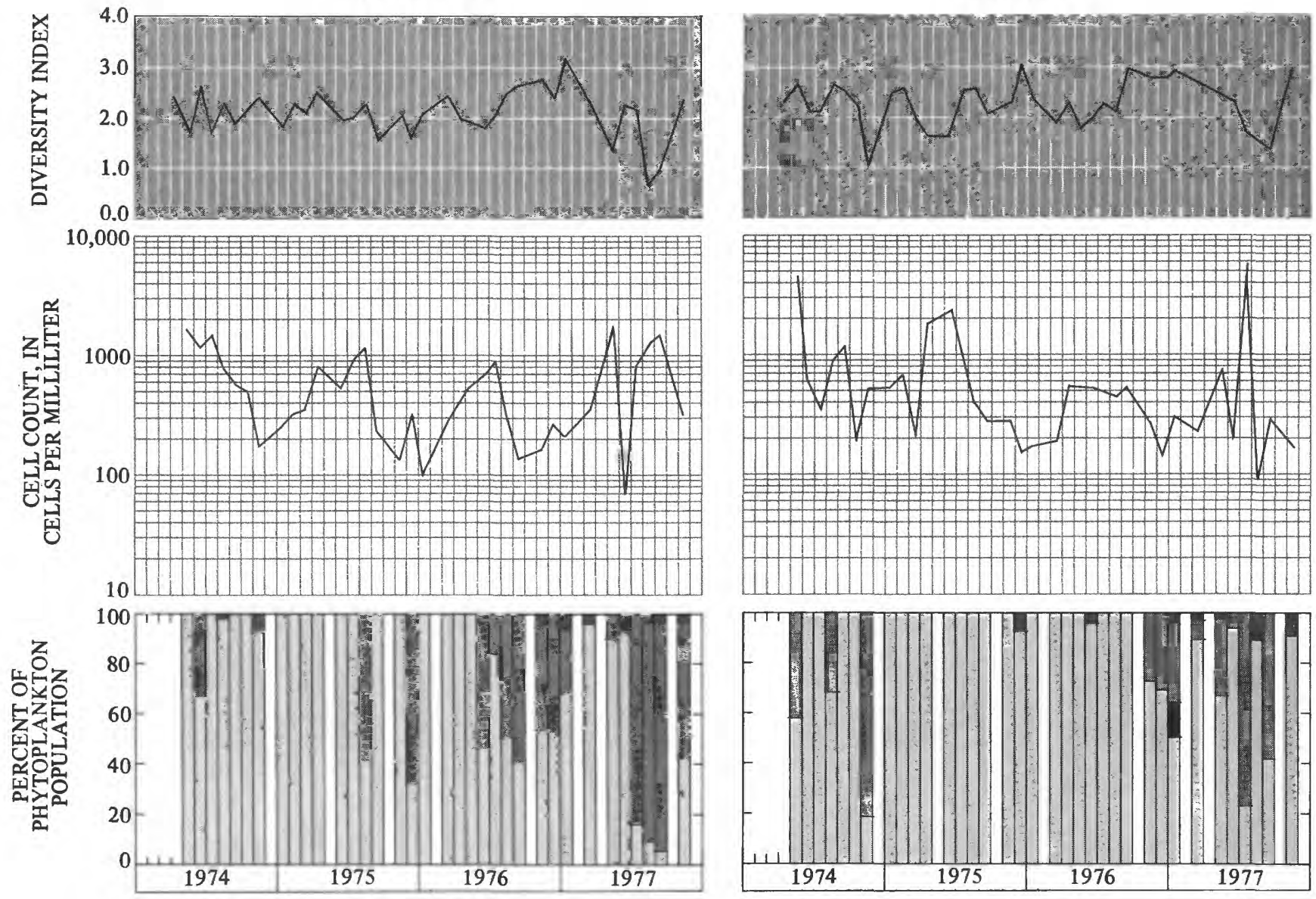

EXPLANATION

Diatoms
Blue-green algae
Green algae
Yellow-brown algae

insect populations between the spring and the stream may be because discharge from springs is a major source of streamflow at base flow.

\section{Community Structure}

Taxonomic and population data may be used to compute a numerical index that can be used to relate community structure to water quality in a stream. Hilsenhoff (1977; written commun., 1980) has used this concept to evaluate water quality in Wisconsin streams, and his work provides the basis for evaluation of water quality in the Nederlo Creek basin with respect to aquatic invertebrates. The term "water quality" as used by Hilsenhoff refers primarily to relative disturbance or organic enrichment indicated by measurements such as biochemical oxygen de- mand and concentrations of dissolved oxygen, suspended solids, and total nitrogen.

In the system used by Hilsenhoff, taxonomic and population data are used to compute a biotic index (B.I.) value for the stream from which a benthic invertebrate sample was collected. The computed index is then compared with B.I. values for streams where water-quality conditions are known to arrive at an estimate of overall water quality in the sampled stream. The formula used to compute B.I. is similar to one originally proposed by Chutter (1972):

$$
\text { B.I. }=\Sigma n_{\mathrm{i}} \mathrm{a}_{\mathrm{i}} / \mathrm{N}
$$



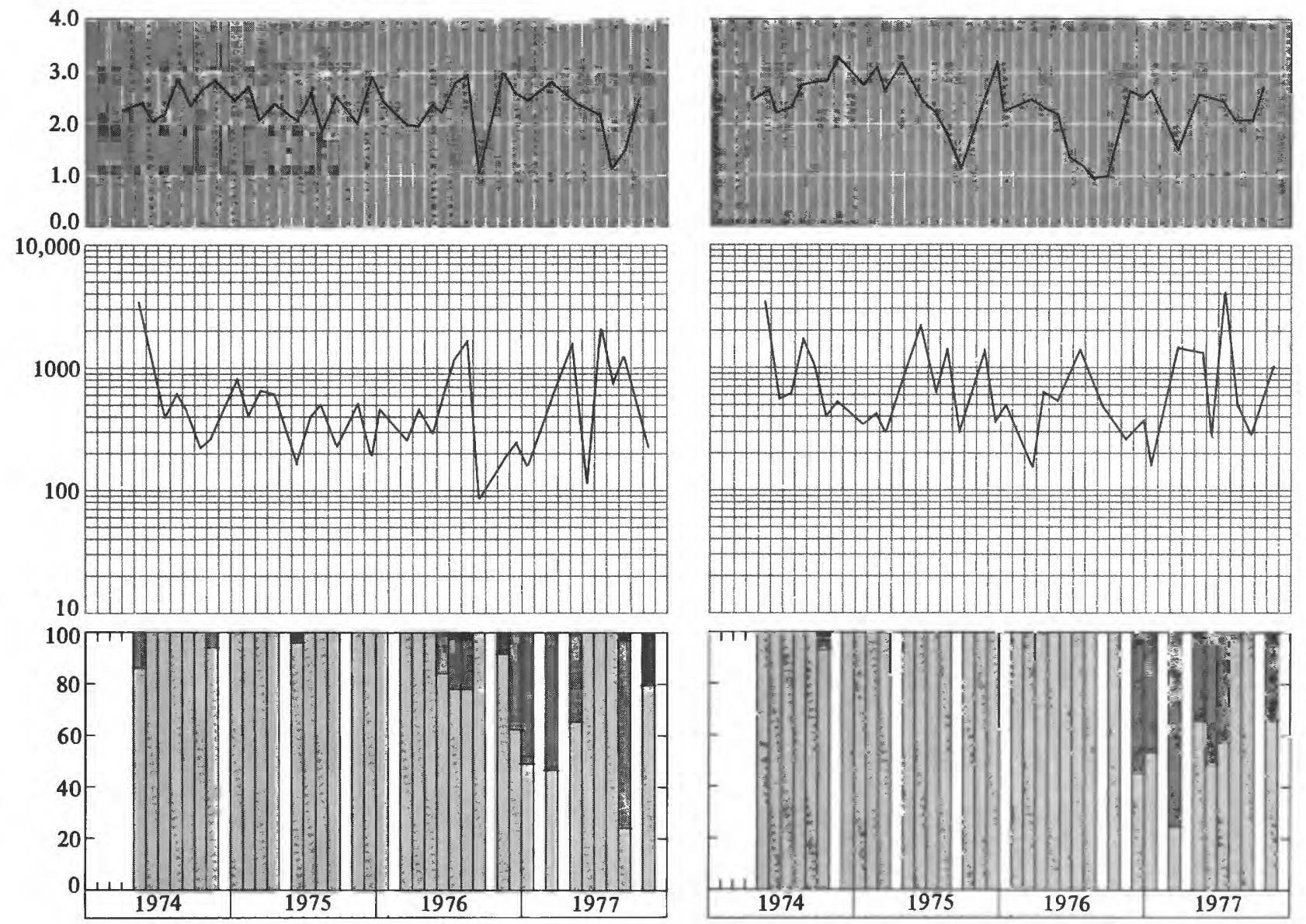

cell count, and community composition.

where:

$n_{i}=$ the number of individuals of a particular species found in the sample,

$a_{i}=$ an index value assigned to that taxon, and

$\mathrm{N}=$ the total number of individuals in the sample.

The index values $\left(a_{i}\right)$ for each taxon range from 0-5 and are based on the relative tolerance to disturbance or organic enrichment shown by the organism. A value of 0 indicates that the organism is found only in streams with very high water quality, and a value of 5 is assigned to species known to occur in highly disturbed or enriched streams. Intermediate values are assigned to organisms with tolerances between these extremes. Index values are not assigned to organisms having a wide range of waterquality tolerance or whose tolerance is unknown.

Values of $a_{i}$ assigned to species found in samples from Nederlo Creek are given in table 6; the values are those assigned to the taxa by Hilsenhoff (written commun., 1980). The preponderance of low $a_{i}$ values (generally in the range 0-3) in table 6 supports the conclusion reached after qualitative appraisal of community structure: that the benthic invertebrate community consists primarily of organisms that require a stable environment relatively free of organic enrichment.

Hilsenhoff (written commun., 1980) has developed the following classification scheme to relate ranges of B.I. values to water quality of Wisconsin streams: 
Table 4. Planktonic algae in Nederlo Creek.

\begin{tabular}{|c|c|c|c|c|}
\hline \multirow{3}{*}{$\begin{array}{l}\text { Order } \\
\quad \text { Family } \\
\text { Genus }\end{array}$} & \multicolumn{4}{|c|}{$\begin{array}{l}\text { Percentage of samples in which } \\
\text { genus was present }\end{array}$} \\
\hline & \multicolumn{4}{|c|}{ Station (see fig. 2) } \\
\hline & 30 & 60 & 70 & 90 \\
\hline \multicolumn{4}{|l|}{ Chlorophyta } & \\
\hline 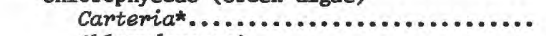 & 3 & 3 & 3 & 3 \\
\hline Chlamydomonas*..................... & 16 & 8 & 8 & 11 \\
\hline 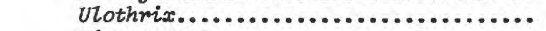 & - & 3 & -- & - \\
\hline Microspora*..................... & 3 & - & - & - \\
\hline Stigeoctonium...................... & - & - & 3 & - \\
\hline Dedogonium.......................... & - & - & 3 & - \\
\hline Schroederia*....................... & - & 6 & 3 & - \\
\hline Ankiatrodeomus*................... & 5 & 3 & 3 & - \\
\hline Tetraedron*........................ & - & 3 & -- & - \\
\hline 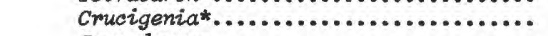 & 3 & - & - & - \\
\hline 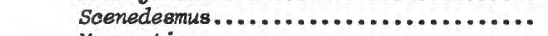 & 3 & 3 & 3 & - \\
\hline 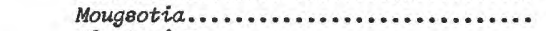 & - & - & - & 3 \\
\hline 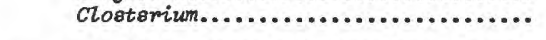 & 3 & - & - & - \\
\hline \multicolumn{5}{|l|}{$\begin{array}{l}\text { Euglenophyta } \\
\text { Euglenophyceae (Euglenoids) }\end{array}$} \\
\hline Eugtena.............................. & 5 & 6 & 17 & 28 \\
\hline 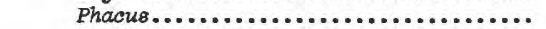 & 3 & - & 6 & 6 \\
\hline Trachelomonas....................... & 5 & 6 & 8 & 3 \\
\hline \multicolumn{5}{|l|}{ Cryptophyceae } \\
\hline 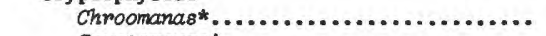 & 3 & - & 3 & - \\
\hline 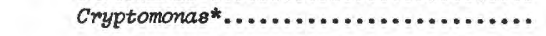 & 14 & 3 & - & 8 \\
\hline \multicolumn{5}{|l|}{ Pyrrophyta } \\
\hline \multicolumn{5}{|l|}{ Dinophyceae (Dinof lagellates) } \\
\hline Gymmodinium* $\quad . . . . . . . . . . . . .$. & 5 & - & 3 & 3 \\
\hline Gienodinium* $\quad . . . . . . . . . . . . . .$. & 3 & - & 3 & 6 \\
\hline \multicolumn{5}{|l|}{ Chrysophyta } \\
\hline Chrysophyceae (Yellow-brown algae) & & & & \\
\hline 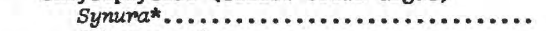 & - & 3 & - & -- \\
\hline Ochromonas*....................... & 3 & 3 & 3 & - \\
\hline Bacillariophyceae (Diatoms) & & & & \\
\hline 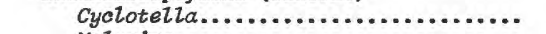 & 16 & 22 & 17 & 8 \\
\hline Molosira.......................... & 3 & 31 & 19 & 8 \\
\hline 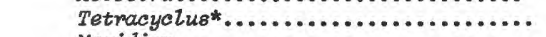 & - & - & - & 3 \\
\hline 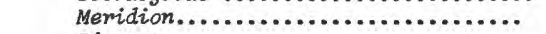 & 32 & 31 & 8 & 14 \\
\hline 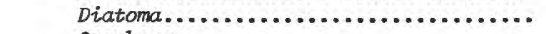 & 5 & 17 & 28 & 67 \\
\hline 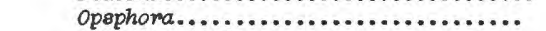 & 3 & - & - & - \\
\hline Astsmionella & - & 3 & -- & - \\
\hline 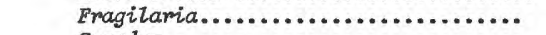 & 5 & 22 & 14 & 6 \\
\hline Synedra........................... & 46 & 61 & 61 & 72 \\
\hline 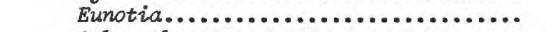 & -- & - & - & 3 \\
\hline 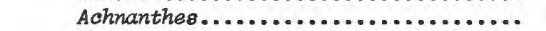 & 78 & 86 & 89 & 83 \\
\hline Cocconeis.......................... & 43 & 78 & 81 & 83 \\
\hline Rhoichosphenia.................... & 14 & 33 & 17 & 14 \\
\hline 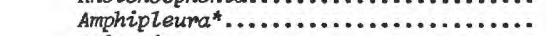 & - & 3 & - & - \\
\hline 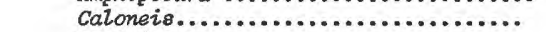 & 5 & 3 & 6 & 8 \\
\hline 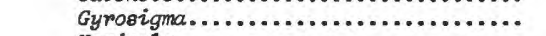 & 5 & 3 & - & 3 \\
\hline 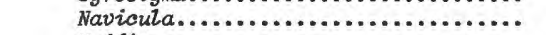 & 89 & 86 & 100 & 100 \\
\hline Neidium......................... & 3 & 3 & 6 & 8 \\
\hline 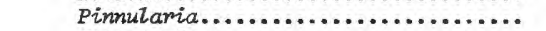 & 3 & 6 & 6 & 17 \\
\hline Stauroneis........................ & 3 & 3 & 8 & 6 \\
\hline Gomphonema........................ & 86 & 86 & 92 & 81 \\
\hline Amphora........................... & 5 & 6 & 11 & 3 \\
\hline 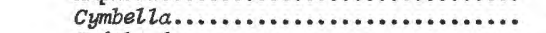 & 30 & 61 & 78 & 83 \\
\hline 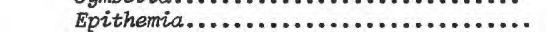 & - & 3 & - & - \\
\hline Rhopalodia*.......................... & - & - & - & 3 \\
\hline 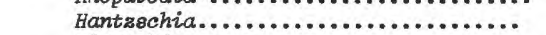 & 8 & - & - & 3 \\
\hline Nitzschia....................... & 84 & 92 & 94 & 94 \\
\hline Cymatopleura..................... & 3 & 17 & 33 & 58 \\
\hline 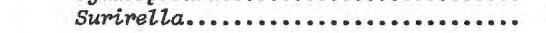 & 54 & 36 & 53 & 69 \\
\hline $\begin{array}{l}\text { Cyanophyta } \\
\text { Myxophyceae (Blue-green algae) }\end{array}$ & & & & \\
\hline 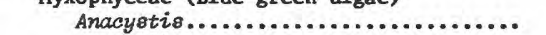 & 3 & 3 & - & 3 \\
\hline Agmenellum....................... & 5 & 6 & -- & - \\
\hline 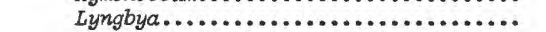 & 3 & 3 & 11 & - \\
\hline Oscillatoma....................... & 49 & 39 & 31 & 28 \\
\hline 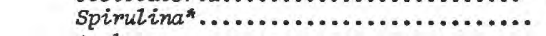 & - & - & - & 3 \\
\hline 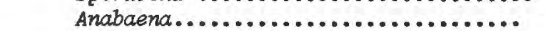 & - & - & 3 & - \\
\hline 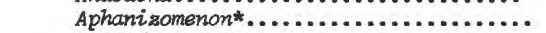 & 3 & -- & - & - \\
\hline 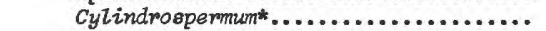 & - & 3 & -- & - \\
\hline 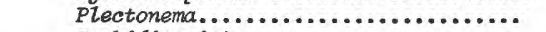 & 3 & - & 3 & - \\
\hline 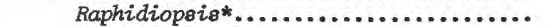 & 3 & - & - & - \\
\hline
\end{tabular}

*Genus present in periphyton but not in phytoplankton. 
Table 5. Characteristics of sites where benthic invertebrate samples were collected.

[All dimensions are in feet]

\begin{tabular}{|c|c|c|c|c|c|}
\hline & \multicolumn{5}{|c|}{ Station } \\
\hline & 30 & 55 & 60 & 62 & 70 \\
\hline \multicolumn{6}{|l|}{$\begin{array}{l}\text { Characteristics of riffle } \\
\text { where sample was collected }\end{array}$} \\
\hline Approximate length & Continuous & 1 & 1 & 25 & 10 \\
\hline Approximate width & $1-1.5$ & $0.5-1$ & $2-3$ & .5 & 12 \\
\hline Approximate water depth & .2 & .2 & $.2-.3$ & .2 & .5 \\
\hline \multicolumn{6}{|l|}{ Bed material } \\
\hline Silt & & & & & $\mathrm{x}$ \\
\hline Sand & $\mathbf{X}$ & & & & , \\
\hline Gravel & $\mathrm{X}$ & & $\mathrm{X}$ & $\mathrm{X}$ & $\mathrm{X}$ \\
\hline $\begin{array}{l}\text { Rocks (less than } \\
0.5 \mathrm{ft} \text { in diameter) }\end{array}$ & $\mathrm{x}$ & $\mathrm{X}$ & & $\mathrm{X}$ & $\mathrm{x}$ \\
\hline $\begin{array}{l}\text { Rocks (greater than } \\
0.5 \mathrm{ft} \text { in diamter) }\end{array}$ & $\mathrm{x}$ & $\mathrm{x}$ & $\mathrm{X}$ & & $\mathrm{X}$ \\
\hline \multicolumn{6}{|l|}{$\begin{array}{l}\text { Characteristics of pool upstream } \\
\text { from riffle }\end{array}$} \\
\hline Approximate length & -- & $10-30$ & $10-25$ & $15-35$ & $20-50$ \\
\hline Approximate width & -- & $2-3$ & $3-4$ & $10-15$ & $10-15$ \\
\hline Approximate water depth & -- & $.5-2$ & $.5-1$ & $.5-1$ & $1-1.5$ \\
\hline
\end{tabular}


Table 6. Distribution of benthic invertebrate species in Nederlo Creek and a tributary spring.

[X indicates station where species was found; * indicates dominant species]

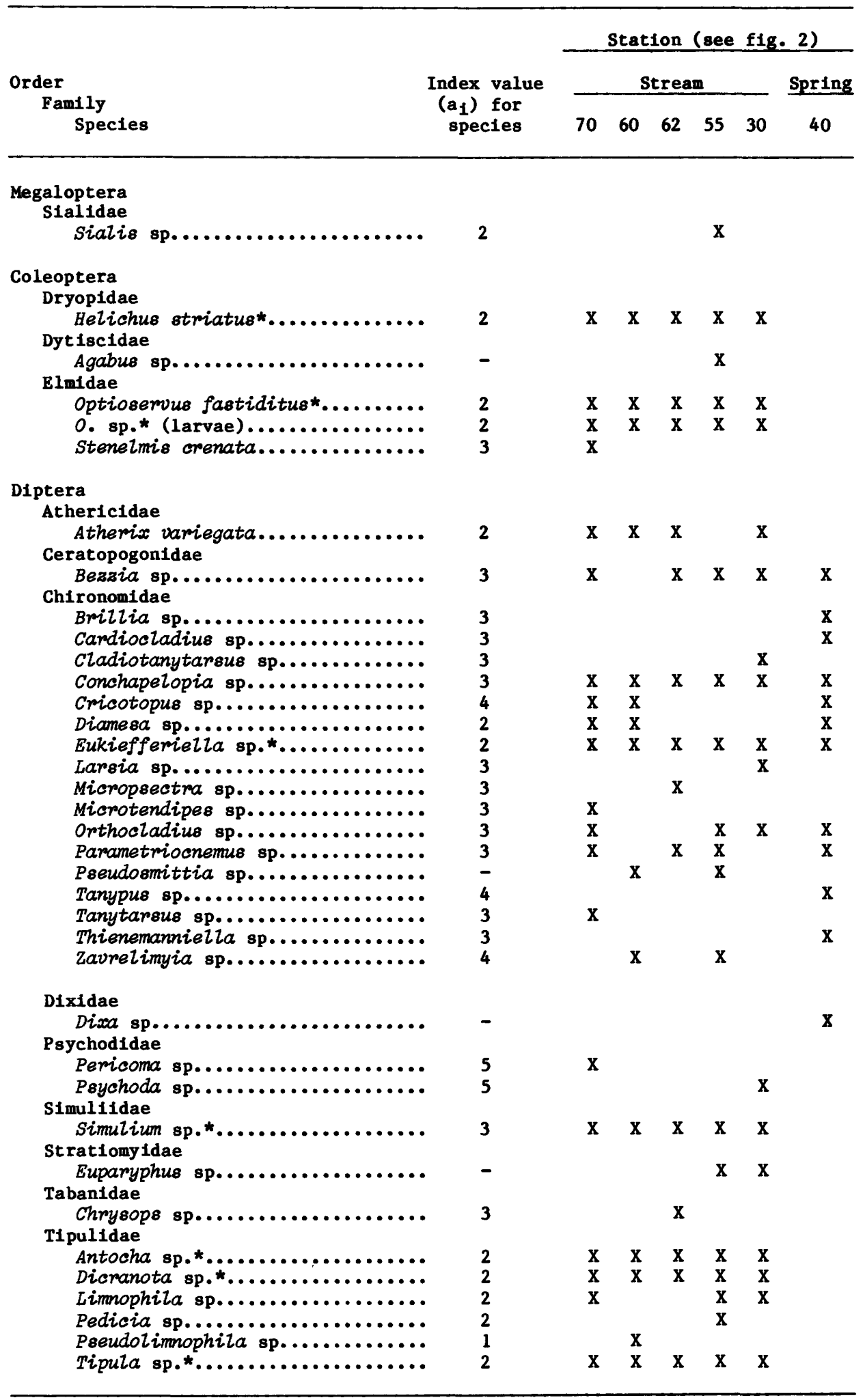


Table 6. Distribution of benthic invertebrate species in Nederlo Creek and a tributary spring.--Continued.

[X Indicates station where species was found; * indicates dominant species]

\begin{tabular}{|c|c|c|c|c|c|c|c|}
\hline \multirow{3}{*}{$\begin{array}{l}\text { Order } \\
\quad \text { Family } \\
\quad \text { Species }\end{array}$} & \multirow{3}{*}{$\begin{array}{l}\text { Index value } \\
\left(a_{1}\right) \text { for } \\
\text { spectes }\end{array}$} & \multicolumn{6}{|c|}{ Station (see fig. 2) } \\
\hline & & \multicolumn{5}{|c|}{ Stream } & \multirow{2}{*}{$\frac{\text { Spring }}{40}$} \\
\hline & & 70 & 60 & 62 & 55 & 30 & \\
\hline \multicolumn{8}{|l|}{$\begin{array}{l}\text { Plecoptera } \\
\text { Capnildae }\end{array}$} \\
\hline $\begin{array}{c}\text { Allocapnia rickeri....................... } \\
\text { Nemouridae }\end{array}$ & 1 & & & & $\mathrm{x}$ & & \\
\hline $\begin{array}{l}\text { Amphinemura delosa.............. } \\
\text { Perlodidae }\end{array}$ & 0 & $\mathrm{x}$ & & $\mathrm{x}$ & $\mathrm{x}$ & $\mathrm{x}$ & $x$ \\
\hline 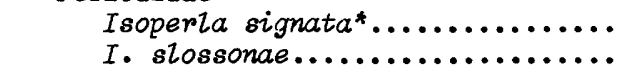 & $\begin{array}{l}1 \\
0\end{array}$ & $\mathrm{x}$ & $\mathrm{x}$ & $\mathbf{x}$ & $\begin{array}{l}x \\
x\end{array}$ & $\begin{array}{l}x \\
x\end{array}$ & \\
\hline \multicolumn{8}{|l|}{$\begin{array}{c}\text { Ephemeroptera } \\
\text { Baetidae }\end{array}$} \\
\hline Baetis brunneicolor*............ & 2 & $\mathrm{x}$ & $\mathrm{x}$ & $\mathrm{x}$ & $\mathrm{x}$ & $\mathrm{x}$ & \\
\hline B. vagans*................... & 1 & $\mathrm{x}$ & $\mathrm{x}$ & $\mathrm{x}$ & $\mathrm{x}$ & $\mathrm{x}$ & $\mathrm{x}$ \\
\hline B. sp. "c".................. & - & $\mathrm{x}$ & $\mathrm{x}$ & & $\mathrm{x}$ & & \\
\hline Heptagentidae & & & & & & & \\
\hline $\begin{array}{l}\text { Stenonema vicarium (= fuscum)*... } \\
\text { Leptophlebildae }\end{array}$ & 1 & $\mathrm{x}$ & $\mathrm{x}$ & $\mathrm{x}$ & $\mathrm{x}$ & $\mathrm{x}$ & \\
\hline 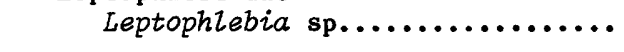 & 2 & & & & & $\mathrm{x}$ & \\
\hline \multicolumn{8}{|l|}{ Hemiptera } \\
\hline $\begin{array}{l}\text { Gerris sp.......................... } \\
\text { Belostomatidae }\end{array}$ & - & & & $\mathrm{x}$ & & & \\
\hline 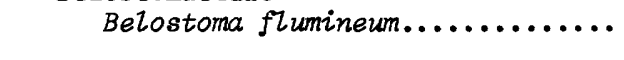 & - & & $\mathrm{x}$ & & & & \\
\hline \multicolumn{8}{|l|}{ Tr1choptera } \\
\hline $\begin{array}{l}\text { Brachycentridae } \\
\text { Brachycentrus americanus*........ } \\
\text { Glossomatidae }\end{array}$ & 0 & $\mathrm{x}$ & $\mathrm{x}$ & $\mathrm{x}$ & $\mathrm{X}$ & $\mathrm{x}$ & \\
\hline $\begin{array}{l}\text { Glossosoma sp.*.............. } \\
\text { Helicopsychidae }\end{array}$ & 1 & $\mathrm{x}$ & $\mathrm{x}$ & $\mathrm{x}$ & $\mathrm{x}$ & $\mathrm{x}$ & $\mathrm{x}$ \\
\hline $\begin{array}{l}\text { Helicopsyche borealis............. } \\
\text { Hydropsychidae }\end{array}$ & 2 & $\mathrm{x}$ & & & & & \\
\hline Chematopsyche sp.*............ & 3 & $\mathrm{x}$ & $\mathrm{X}$ & $\mathrm{x}$ & $\mathrm{x}$ & $\mathrm{x}$ & \\
\hline Hydropsyche betteni............. & 3 & $\mathrm{x}$ & & $\mathrm{x}$ & & & \\
\hline Parasyche apicalis.............. & 0 & & & & & & $\mathrm{x}$ \\
\hline Symphitopsyche bifida (group).... & 3 & $\mathrm{x}$ & $\mathrm{x}$ & & & & \\
\hline 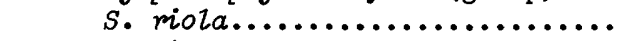 & 2 & $\mathrm{x}$ & $\mathrm{x}$ & & & & \\
\hline s. slossonae................. & 2 & $\mathrm{x}$ & $\mathrm{x}$ & $\mathrm{x}$ & $\mathrm{x}$ & $\mathrm{x}$ & \\
\hline 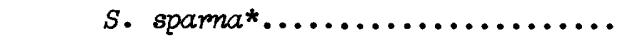 & 1 & $\mathrm{x}$ & & $\mathrm{x}$ & $\mathrm{x}$ & $\mathrm{x}$ & \\
\hline Lepidostomatidae & & & & & & & \\
\hline $\begin{array}{l}\text { Lepidostoma sp................. } \\
\text { Leptoceridae }\end{array}$ & 1 & & & & & & $\mathrm{X}$ \\
\hline 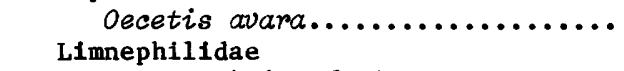 & 1 & & $\mathrm{X}$ & $\mathrm{x}$ & $\mathrm{x}$ & & \\
\hline Hesperophyzax designatus......... & 1 & & & $\mathrm{x}$ & $\mathrm{x}$ & $\mathrm{x}$ & $\mathrm{x}$ \\
\hline 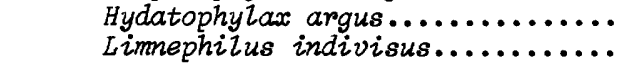 & $\begin{array}{l}1 \\
2\end{array}$ & & & & $\begin{array}{l}\mathrm{X} \\
\mathrm{X}\end{array}$ & & \\
\hline 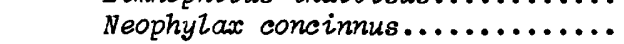 & 2 & & & $\mathrm{x}$ & $\mathrm{x}$ & & $\mathrm{x}$ \\
\hline $\begin{array}{l}\text { Pycnopsyche lepida............. } \\
\text { Philopotamidae }\end{array}$ & 2 & $\mathrm{x}$ & $\mathrm{x}$ & $\mathrm{x}$ & & $\mathrm{x}$ & \\
\hline $\begin{array}{l}\text { Chimarra aterrina*.............. } \\
\text { Phrygane1dae }\end{array}$ & 2 & $\mathrm{x}$ & $\mathrm{x}$ & $\mathrm{x}$ & & $\mathrm{x}$ & \\
\hline $\begin{array}{l}\text { Ptilostomis ocellifera........... } \\
\text { Sericostomatidae }\end{array}$ & 2 & & & & $\mathrm{x}$ & & \\
\hline Agarodes distinctum............. & 2 & & $\mathrm{x}$ & & & & \\
\hline
\end{tabular}


Water-quality determination from biotic index values*

Biotic index Water quality State of the stream

\begin{tabular}{|c|c|c|}
\hline $\begin{array}{c}0-1.75 \\
1.75-2.25\end{array}$ & $\begin{array}{l}\text { Excellent } \\
\text { Very good }\end{array}$ & $\begin{array}{l}\text { Clean, undisturbed } \\
\text { Slight enrichment or } \\
\text { disturbance }\end{array}$ \\
\hline $25-2.75$ & Good & $\begin{array}{l}\text { Some enrichment or } \\
\text { disturbance }\end{array}$ \\
\hline $75-3.50$ & Fair & $\begin{array}{l}\text { Moderate enrichment } \\
\text { or disturbance }\end{array}$ \\
\hline $.50-4.25$ & Poor & $\begin{array}{l}\text { Significant enrichment } \\
\text { or disturbance }\end{array}$ \\
\hline$>4.25$ & Very poor & $\begin{array}{l}\text { Gross enrichment } \\
\text { or disturbance }\end{array}$ \\
\hline
\end{tabular}

*After Hilsenhoff, written commun., 1980

Biotic index values calculated for the five sampling sites on Nederlo Creek are summarized in table 7. Mean and median B.I. values for all sites are less than 2.25 , and values for individual samples were also less than 2.25 except in two cases. According to the classification scheme, the calculated B.I. values indicate little organic enrichment or disturbance. This is corroborated by the long-term stability and diversity of benthic invertebrate communities noted at each of the sampling sites.

\section{Trout Habitat}

Trout habitat in Nederlo Creek and factors influencing it are typical of many headwater trout streams in southwestern Wisconsin. The streams are generally able to sustain wild trout, but many factors interact to limit trout reproduction and survival and keep the population below the potential carrying capacity of the stream. Frequently, wild trout are too scarce for good fishing, and stocking becomes necessary.

Characteristics of the stream channel and riparian land use and vegetation are likely factors limiting trout population. The stream has some pools of suitable size and configuration for trout, but is otherwise characterized by riffles and shallow pools. The riffles provide suitable substrate for benthic organisms, thus supporting fish-food organisms, but the pools generally lack adequate cover and living space for trout. Limitations on bank cover were discussed previously. Instream cover is also sparse except for the, at times, dense beds of Nasturtium, especially in the north fork. The Nasturtium provides excellent cover for fingerling trout and is a substrate for fish-food organisms. Size and distribution of bed materials is a limiting factor on reproduc-

Table 7. Biotic index values for sampling stations on Nederlo Creek.

\section{[Locations of sampling stations shown in figure 2]}

\begin{tabular}{|c|c|c|c|c|c|}
\hline Date & $\begin{array}{c}\text { Station } \\
30\end{array}$ & $\begin{array}{c}\text { Station } \\
55\end{array}$ & $\begin{array}{c}\text { Station } \\
60\end{array}$ & $\begin{array}{c}\text { Station } \\
\quad 62\end{array}$ & $\begin{array}{c}\text { Station } \\
70\end{array}$ \\
\hline 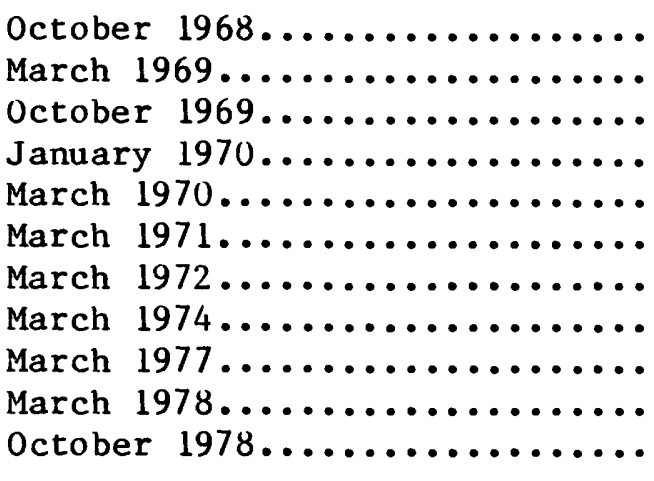 & $\begin{array}{l}1.75 \\
1.20 \\
1.76 \\
1.61 \\
1.96 \\
1.00 \\
1.52 \\
1.59 \\
1.60 \\
1.89\end{array}$ & $\begin{array}{l}1.44 \\
1.36 \\
2.00 \\
.--- \\
1.98 \\
1.82 \\
1.83 \\
1.85 \\
1.58 \\
1.54 \\
2.46\end{array}$ & $\begin{array}{l}2.01 \\
--0 \\
2.01 \\
2.11 \\
2.15 \\
1.86 \\
1.27 \\
1.77 \\
1.29 \\
1.36 \\
1.84\end{array}$ & $\begin{array}{l}1.47 \\
1.14 \\
1.60 \\
1.66 \\
1.84 \\
2.11 \\
.70 \\
1.72 \\
2.08 \\
1.36 \\
2.20\end{array}$ & $\begin{array}{l}2.05 \\
2.10 \\
1.73 \\
1.53 \\
1.78 \\
1.98 \\
1.86 \\
--2- \\
2.55 \\
1.46 \\
1.33\end{array}$ \\
\hline $\begin{array}{l}\text { Median } \\
\text { Mean } \\
\text { Standard deviation } \\
\text { Number of values }\end{array}$ & $\begin{array}{r}1.48 \\
1.59 \\
10^{.30}\end{array}$ & $\begin{array}{r}1.91 \\
1.79 \\
.32\end{array}$ & $\begin{array}{r}1.71 \\
1.77 \\
10^{.39}\end{array}$ & $\begin{array}{r}1.45 \\
1.63 \\
11.45\end{array}$ & $\begin{array}{r}1.95 \\
1.84 \\
10^{.36}\end{array}$ \\
\hline
\end{tabular}


tion. Bed material is generally fine sand, silt and clay in pools, and larger rubble and rocks in riffles. Relatively few areas have gravel of proper size distribution for redd construction and spawning. Streambed areas that have suitable spawning substrate and meet other conditions necessary for spawning are scarce.

Water quality is generally suitable for survival and growth of trout. The calcium magnesium bicarbonate type water supports a productive biological system and no major aquatic environmental disturbances are indicated by the composition of the algae and benthic invertebrates. Dissolved-oxygen concentrations do not fall to critically low levels, and water temperatures are within tolerable limits for trout.

The stable base flow in Nederlo Creek is beneficial to trout, but high streamflow caused by overland runoff, although infrequent, may dramatically affect the stream environment. High streamflow may deepen pools and undercut streambanks, which provides additional trout cover and living space, but may also destroy spawning areas and instream vegetative cover. Other studies in Wisconsin indicate that high winter streamflow especially harms trout reproduction and survival (Brynildson and Brynildson, Wisconsin DNR, written comm., 1981).

Feeding habits of brown trout have been found to differ with the size of the trout. Trout less than about 9 in. long feed primarily on invertebrates, whereas the larger fish feed more on forage fish and crayfish (Brynildson and others, 1964). The aquatic invertebrates and forage fish in Nederlo Creek provide ample food for trout.

Although feeding habits of local trout were not investigated, they are probably similar to those of trout in nearby streams. The benthic invertebrate community is similar to that found by Avery (1978) in Seas Branch Creek in Vernon County $(20 \mathrm{mi}$ north-northeast of Nederlo Creek in a similar physical and hydrologic setting). Included in that investigation was a study of brown trout feeding habits, which showed that Trichoptera, Diptera, and Coleoptera were the invertebrate groups most often found in the stomachs of trout. These groups are well represented in Nederlo Creek. Other major food organisms indentified by Avery were amphipods (primarily Gammarus sp.), crayfish, and forage fish, all of which are abundant in Nederlo Creek.

Species composition of forage fish is similar to that in cther small trout streams in the Kickapoo
River basin (Avery, 1978; Wirth and Mason, 1974; Becker, 1966; Greene, 1935). Species of forage fish found in the stream, and their relative abundance, are listed in table 8. Darters and minnows are dominant in numbers, but most of the forage fish biomass consists of white suckers. Trout represent only a small part of the fish population, both in numbers and biomass. Forage fish population did not change significantly during the study.

\section{Trout Population Dynamics}

Trout population dynamics was studied in four reaches of Nederlo Creek totaling 2.8 stream miles (fig. 2). Reach A (extending from station 90 to station 70) and reach B (extending from station 70 to the confluence of the north and south forks) cover the main stem of Nederlo Creek. Reach $\mathrm{C}$ is on the south fork, and reach $\mathrm{D}$ is on the north fork.

\section{Study Methods}

Study methods of fish population were basically the same as described by many other investigators (McFadden, 1961; Hunt and others, 1962; White, 1964). The fish population was assessed each fall during 1967-78 using direct current electrofishing equipment. Trout captured were measured and weighed, and young-of-the-year fingerlings were fin-clipped for future identification; stocked trout were distinguished from wild trout by marks they received before release.

From 1967-73, trout population was estimated by the double-run mark and recapture method. Because the electrofishing gear proved to be highly efficient in collecting trout, population estimates during 1974-78 were made on the basis of only one electrofishing run and shocker efficiencies calculated during the years when two runs were made. Data were not collected in reach A during 1969-71.

\section{Trout Populations and Biomass}

Numbers and biomass of brook and brown trout found each fall during 1967-78 are shown in figure 4. The population was always low; it reached a high point of 443 trout of both wild and hatchery origin in 1969 , even through reach A was not included in that year. Only 60 trout were found in 1972, when the population was at its lowest level. Fall biomass ranged from 26 to $91 \mathrm{lb}$ over the 12-year period. 
Table 8. Fish species in Nederlo Creek.

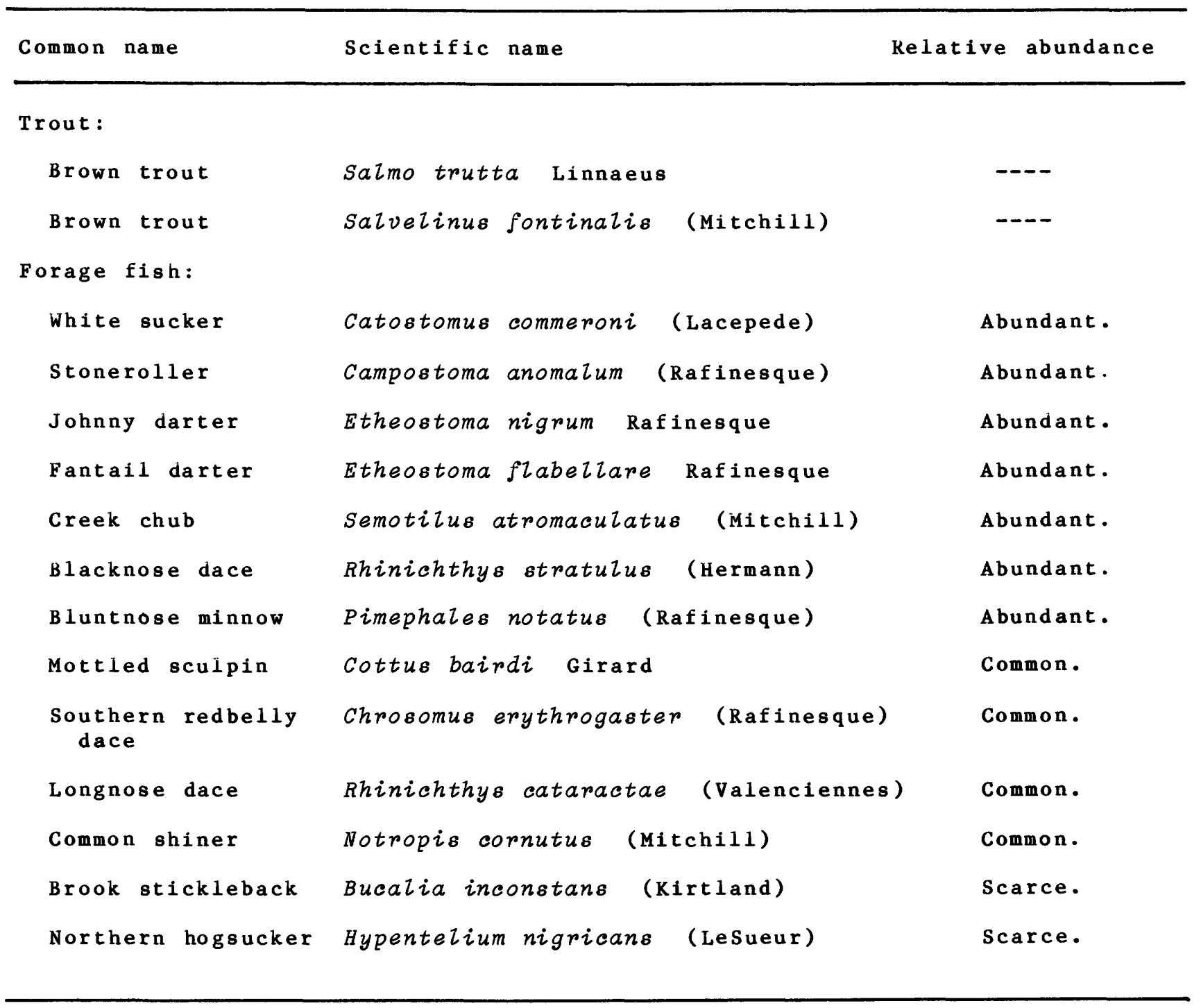

Excluding the years 1969-71, when reach A was not inventoried, a 9-year average fall biomass of both wild and stocked trout was $64 \mathrm{lb}$, or $14 \mathrm{lb} / \mathrm{acre}$. By comparison, the best trout streams in southern Wisconsin hold over $100 \mathrm{lb} /$ acre in the fall (Brynildson and Mason, 1975; Brynildson and Brynildson, written commun., 1981).

In most years, there were more wild than stocked trout, but, during 1973-77, more than half the fall biomass consisted of stocked trout. The stream was stocked with 500 yearling brown trout each spring except for 1970 and 1972 , and 250 brook trout were stocked as fingerlings in the fall of 1968 and 1969. Stocked trout were released in reach $\mathbf{A}$, and most of the relatively small number that survived until fall were captured in that reach. Some brook trout survived to spawning size, and a wild population was established in the stream. The wild brook trout population declined in subsequent years and gradually disappeared (fig. 4).

The size of the wild brown trout population each fall was largely dependent on reproductive success 
BROWN TROUT

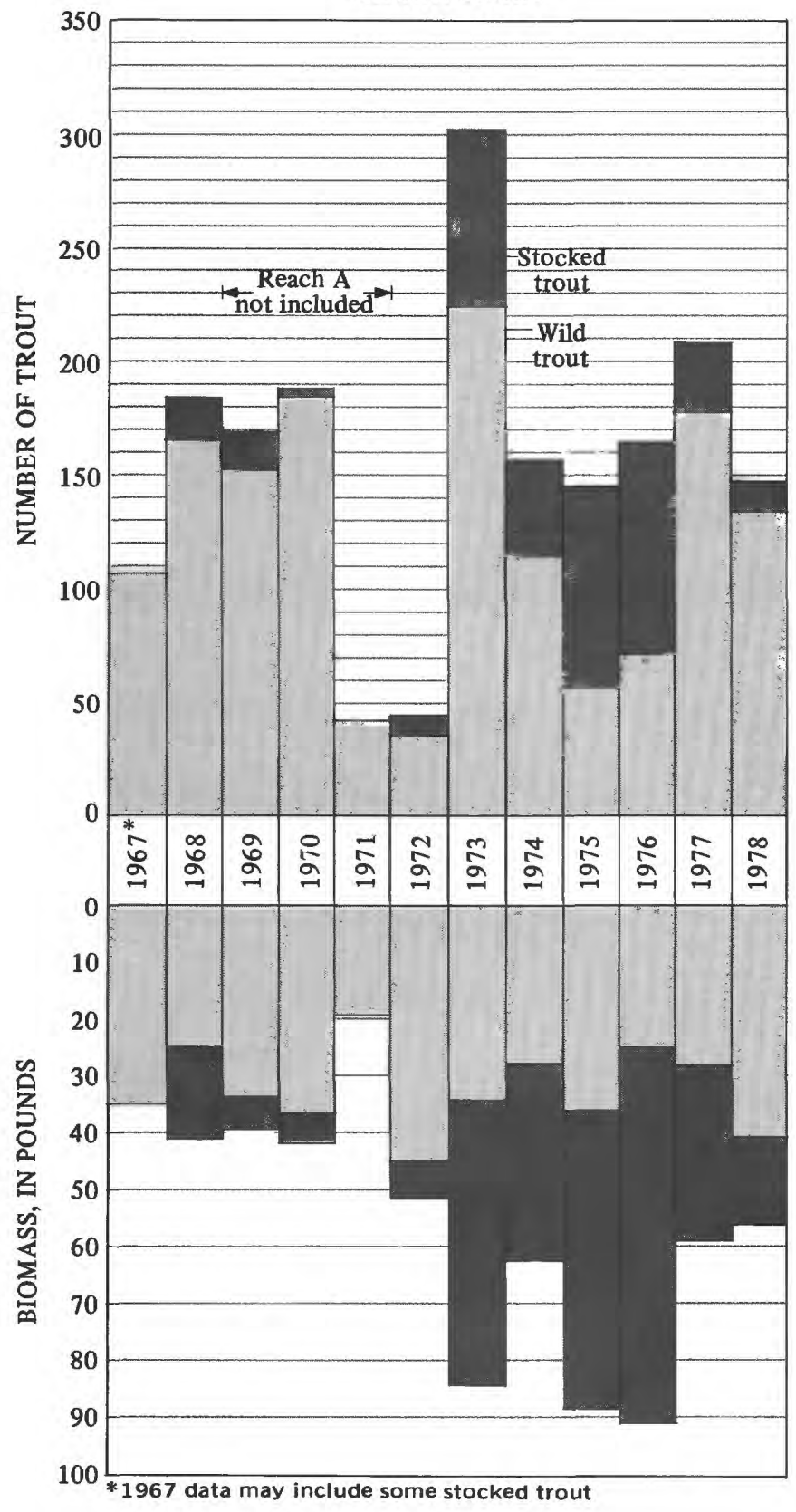

BROOK TROUT

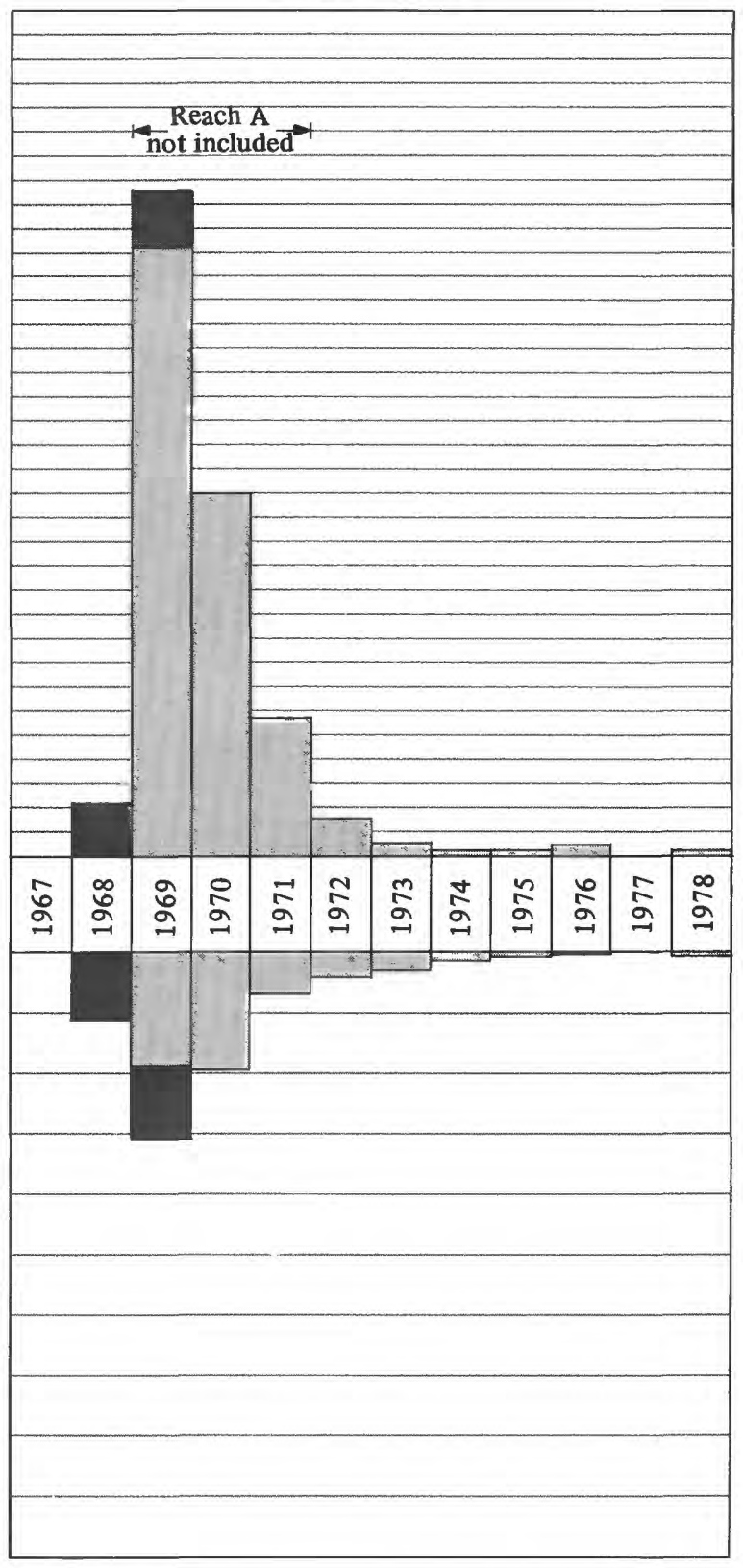

Figure 4. Fall brown and brook trout population and biomass in Nederlo Creek.

the previous fall, because fingerlings normally made up the greatest percentage of the population. Figure 5 shows the fall population and biomass of brown trout by stream reach. The greatest numbers of wild trout were always found in reaches $\mathrm{B}, \mathrm{C}$, and $\mathrm{D}$, where most reproduction occurred. In the early years of the study, some wild brown trout were present in reach C, but after 1971 none were found there.
The floodwater-retention structure constructed during the study has affected the distribution of brown trout in reach D. Table 9 shows the distribution of wild brown trout in reach $\mathrm{D}$ before, during, and after construction. It seems that the structure has had little effect on the downstream trout population. Spawning and reproduction occurred upstream from the structure before it was built, but no redds or spawning-age adults have been observed there 
STREAM REACH A

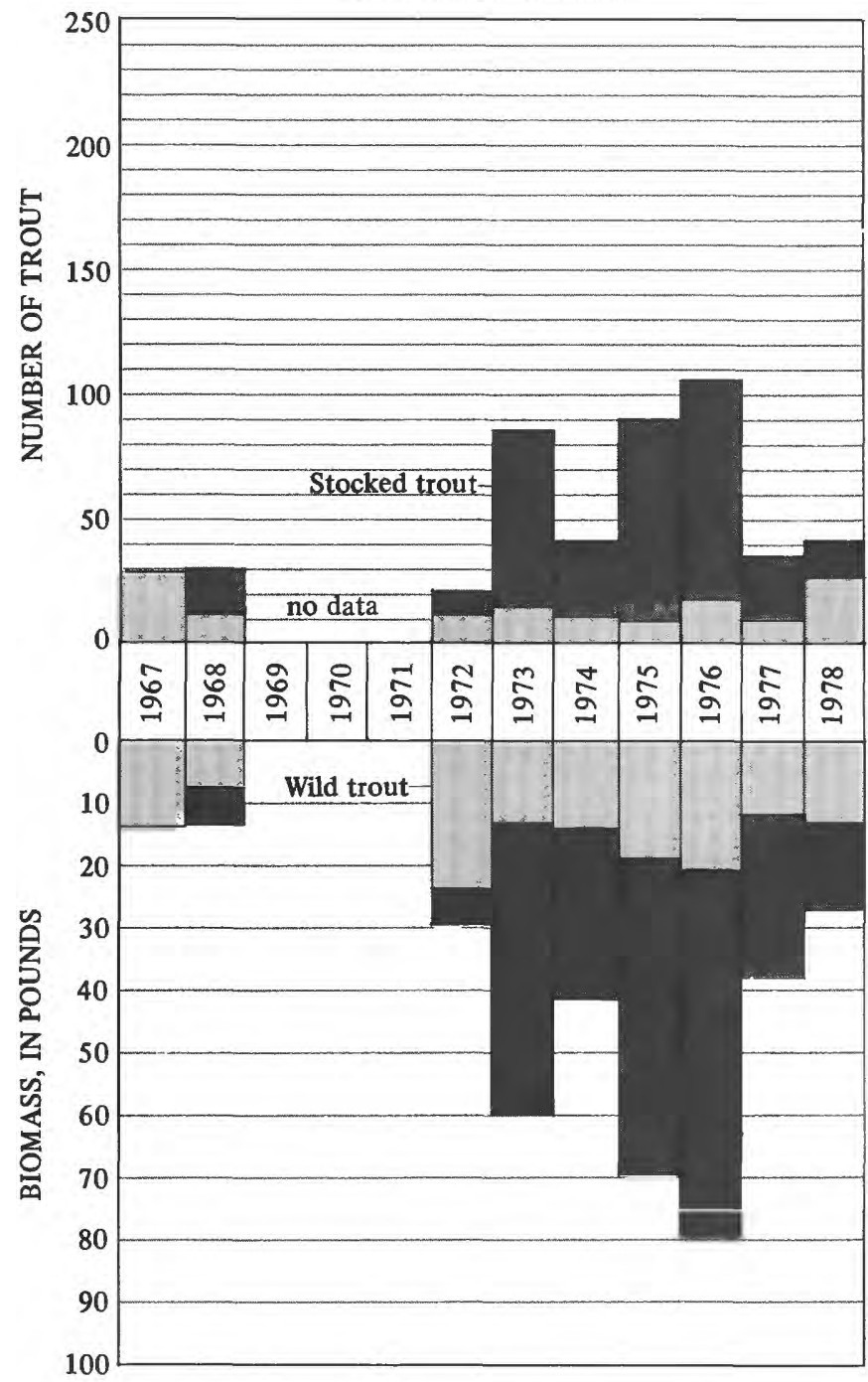

STREAM REACH B

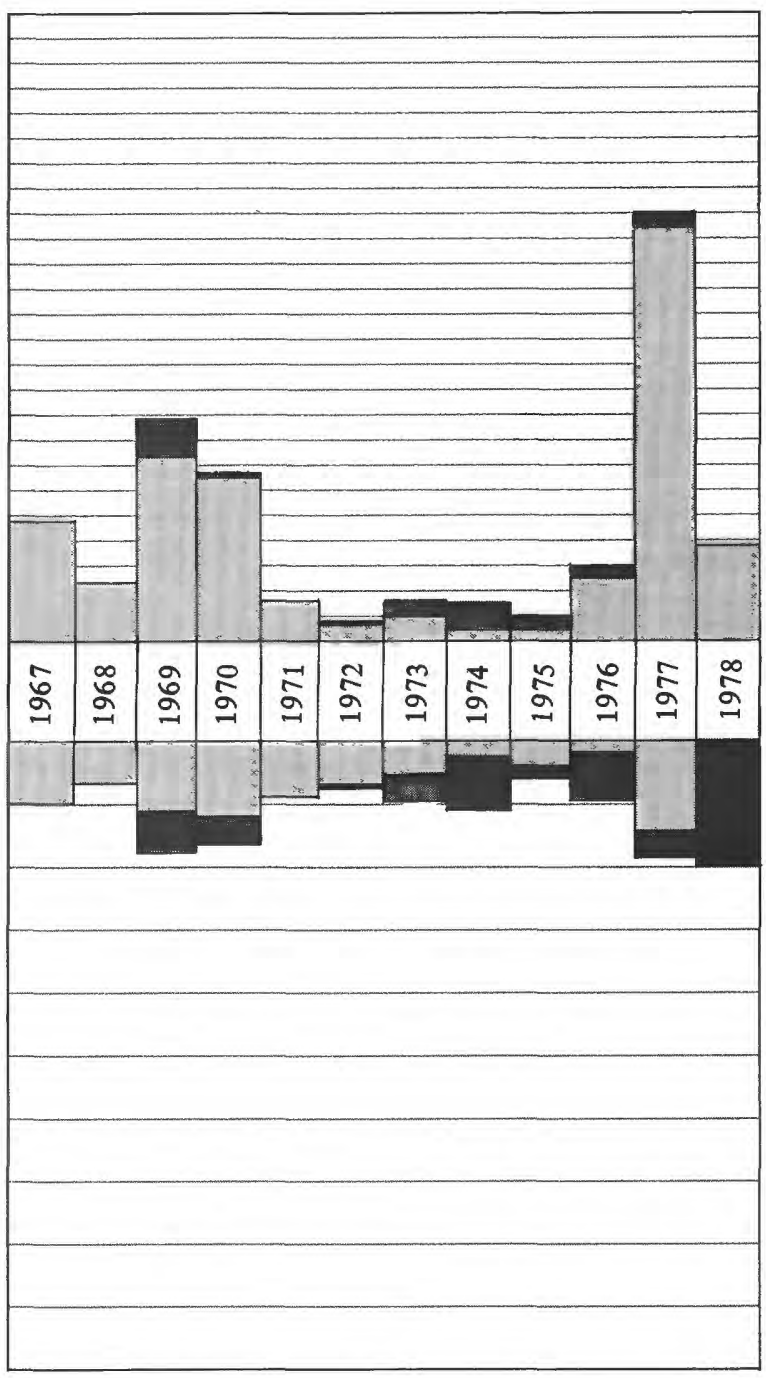

Figure 5. Fall brown trout population since 1975. The structure may impede upstream migration of adult trout. Some fingerlings were found upstream from the structure in 1976 and 1978; they apparently passed upstream through the outlet pipe, and a resident population may be reestablished upstream from the structure in the future.

\section{Reproduction, Survival, and Growth}

Reproductive success of the trout (as measured by the number of fingerlings found in the fall) varied considerably during the 12 -year study period. Success was influenced by the number of adult spawners available as well as by environmental factors such as high streamflow. Locations of spawning sites observed in the stream are shown in figure 6 . The most intense spawning of both brown and brook trout was in the upstream reaches; spawning was observed in reach $\mathbf{A}$, but success was limited.

Fall population of wild brown trout fingerlings captured by electrofishing ranged from 3 in 1972 to 210 in 1973. The largest number of brook trout fingerlings, 251 , was found in 1969 , the year after brook trout were first introduced into the stream. After brook trout stocking was discontinued in 1969, the number of brook trout fingerling declined each fall until the population disappeared. 
STREAM REACH C

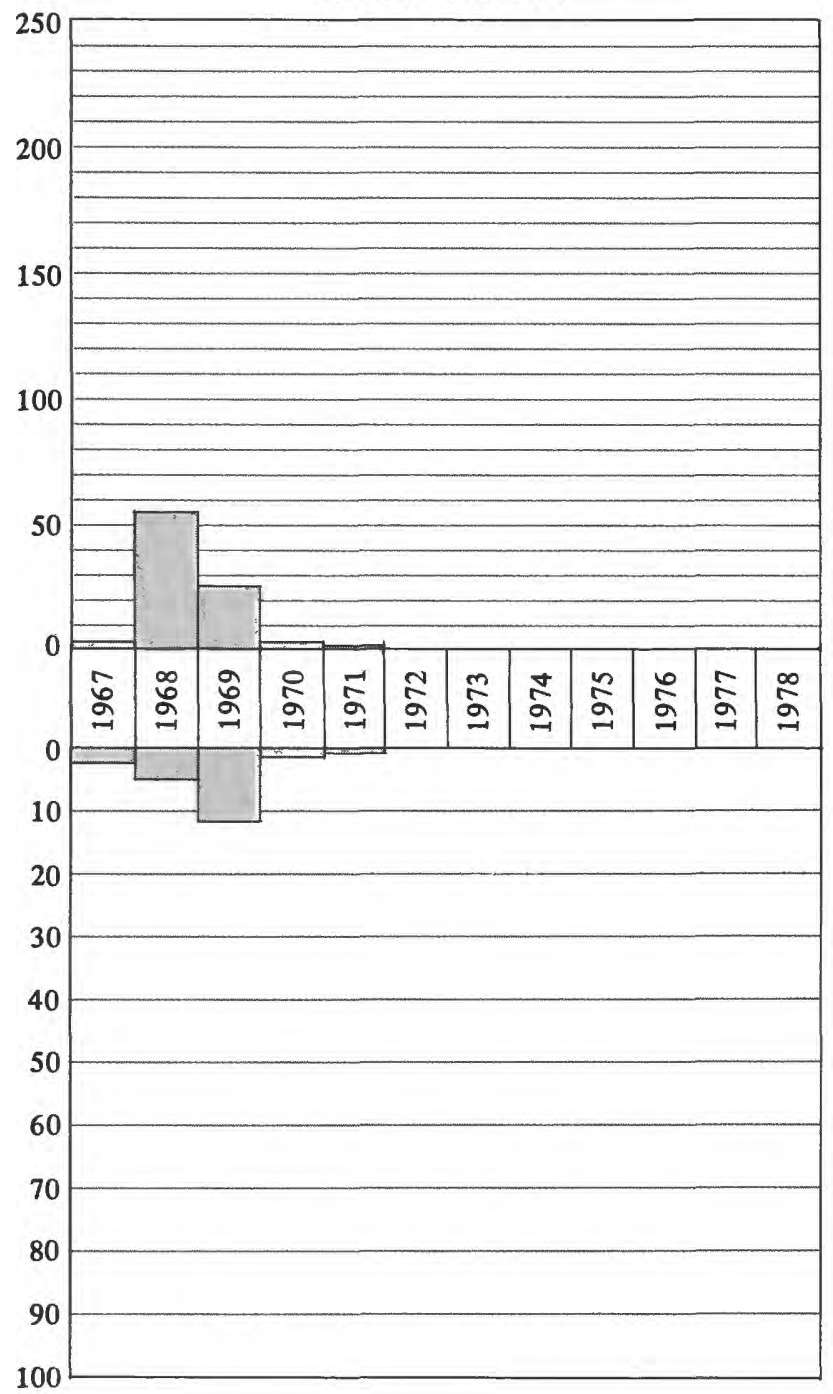

STREAM REACH D

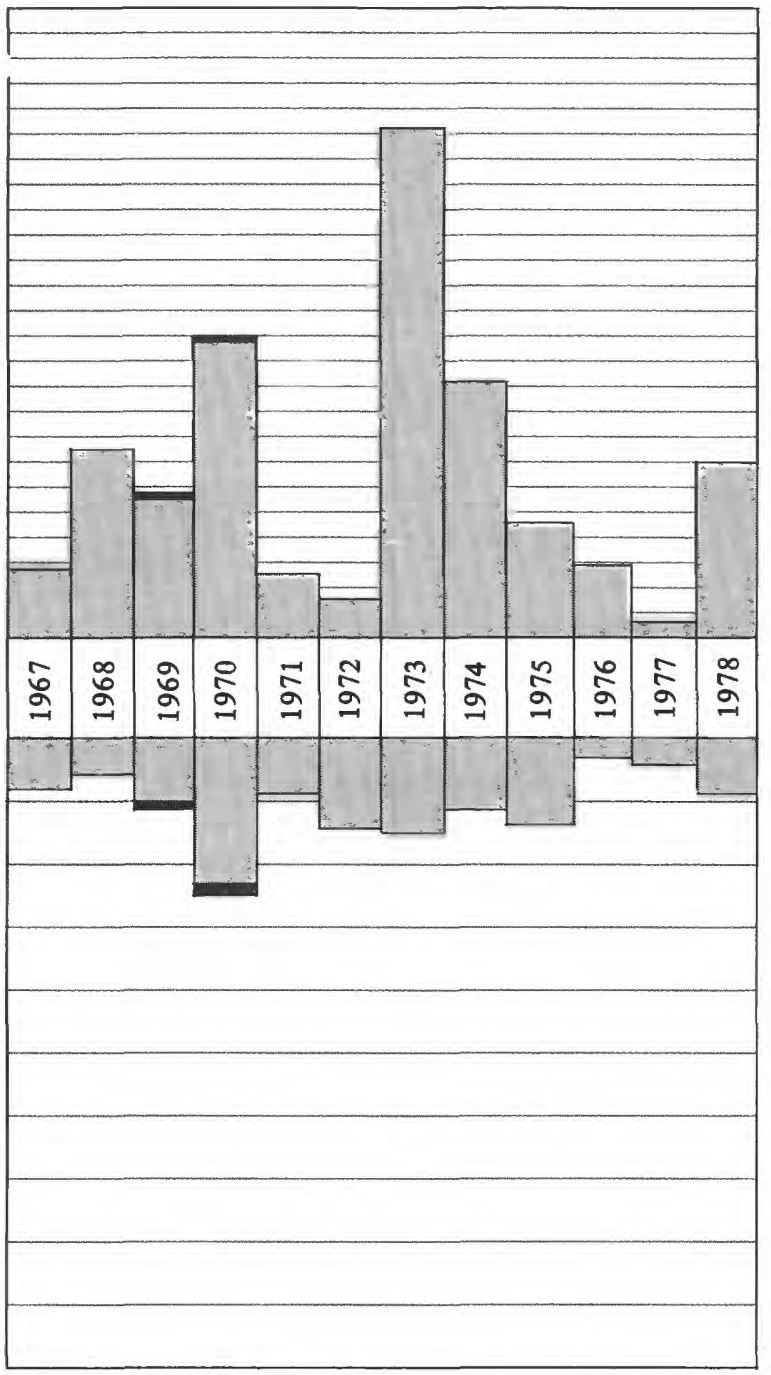

and biomass by stream reach.

Because no data on trout harvest were collected, mortality due to harvest and natural causes cannot be separated, but annual mortality from all causes is high. Survival of fall brown trout fingerlings (age 0) to the following fall (age 1) averaged 30 percent over the study; survival from age 0 to age 2 (three summers) was only 10 percent. Higher brown trout survival rates have been reported in other southern Wisconsin streams; in Black Earth Creek, for example, survival from age 0 to age 1 averaged 45 percent and from age 0 to age 2, 19 percent (Dunst, 1970).
Growth rate of brown trout in Nederlo Creek is comparable to that reported for other trout streams in southern Wisconsin (Brynildson and Brynildson, written commun., 1981; Brynildson, 1957). Wild brown trout fingerlings (age 0 ) averaged 5 in. in length by the first fall, 10 in. at age 1 , and more than 13 in. at age 2 (table 10). Few trout survived beyond age 2, but some age 3 and older fish reached more than 20 in. in length. Brook trout also showed a good growth rate, when present, averaging 6 in. in length by the first fall. The small number of brook trout that survived two summers (age 1) were as long as 13 in. 


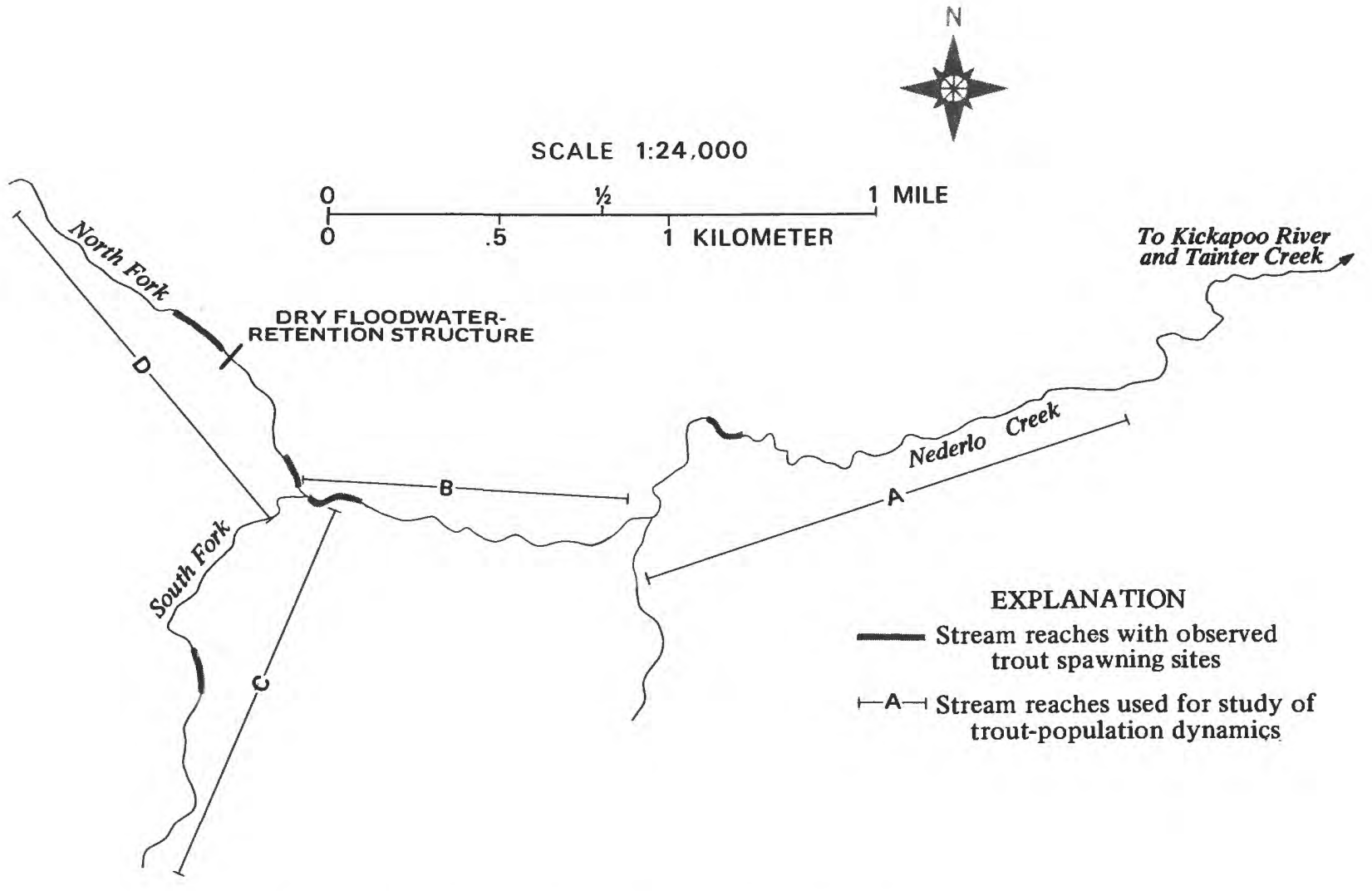

Figure 6. Location of stream reaches with observed trout spawning sites.

Table 9. Distribution of wild brown trout in stream reach $\mathbf{D}$.

\begin{tabular}{lccc}
\hline \multicolumn{4}{c}{ Number of wild trout } \\
\cline { 2 - 3 } Year & $\begin{array}{c}\text { Downstream from } \\
\text { structure }\end{array}$ & $\begin{array}{c}\text { Upstream from } \\
\text { structure }\end{array}$ & Period \\
\hline 1968 & 13 & 62 & \\
1969 & 6 & 48 & Preconstruction \\
1970 & 31 & 87 & \\
1971 & 2 & 24 & Construction \\
1972 & 4 & 11 & \\
1973 & 49 & 152 & Postconstruction \\
1974 & 12 & 89 & \\
1975 & 11 & 33 & \\
1976 & 16 & 13 & \\
1977 & 5 & 12 & \\
1978 & 57 & & \\
\hline
\end{tabular}




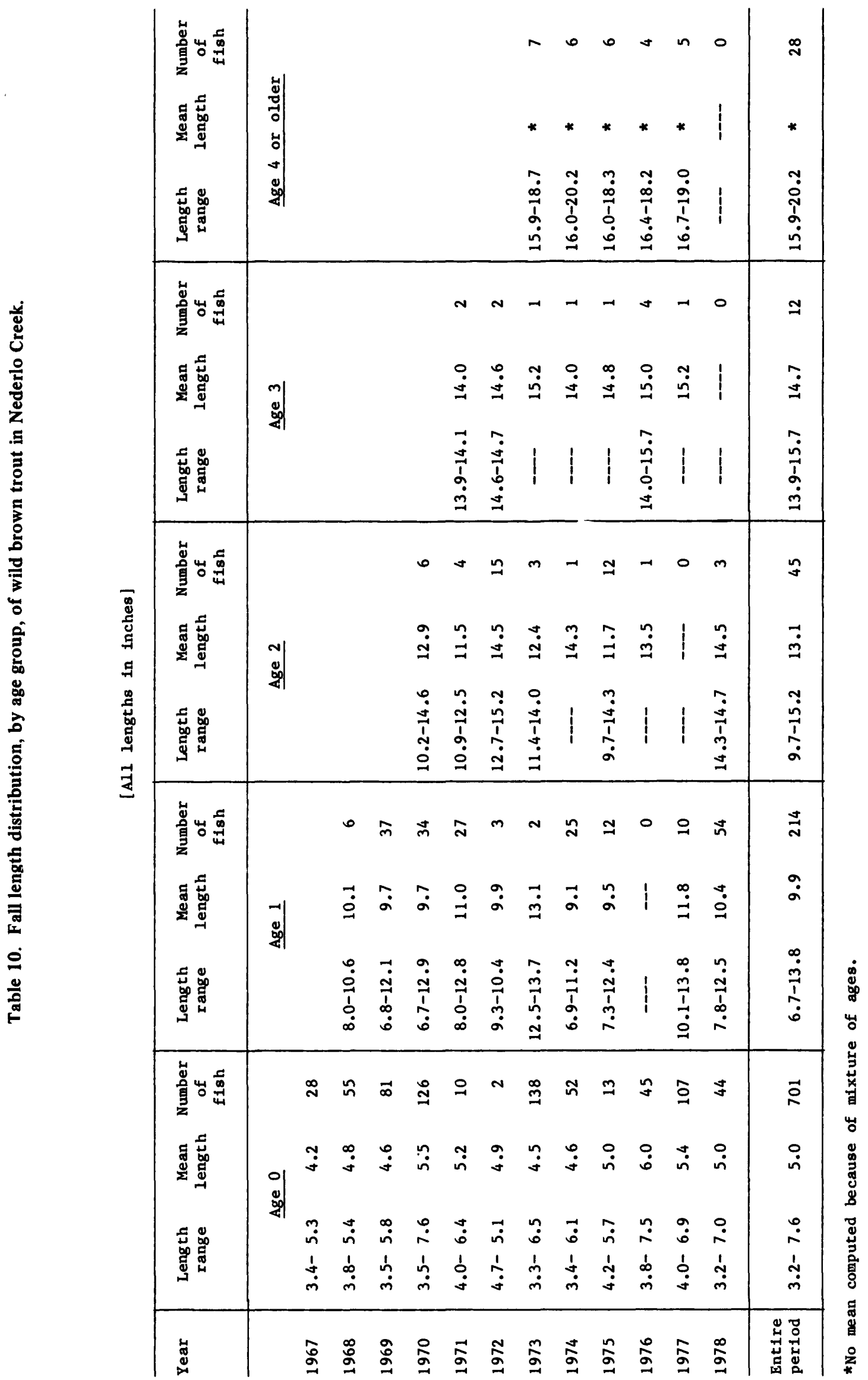




\section{CONCLUSIONS}

This study of aquatic biology in the Nederlo Creek basin has shown that the aquatic community is diverse and reasonably stable, with little indication of environmental disturbance or stress. The most apparent environmental disturbance noted was the destruction of streambank vegetation by livestock, which reduced available trout cover.

Aquatic macrophyte population (dominated by the species Ranunculus aquatilis L., Veronica catenata Penn., and Nasturtium officinale) is reasonably stable and generally varies little from spring to fall. High streamflow seems to have little destructive effect on the macrophytes except for extreme floods. The stability of the aquatic macrophytes enhances their usefulness as cover for trout fingerlings and habitat for benthic invertebrates.

Periphytic and planktonic algae populations are both dominated by diatoms, with the genus Achnanthes dominating both communities. Significant areal (site-to-site) differences in population, if any, are masked by the wide month-to-month population variation at each sampling site. The balance between autotrophic and heterotrophic organisms in the periphyton, as measured by ash-free dry weight and chlorophyll $a$ production, indicates some organic enrichment of the water but no serious environmental disturbance. Most genera of planktonic algae seem to originate in the periphyton, but some true planktonic genera were identified. Phytoplankton populations (cell counts) are highest in the summer; diversity is moderately high year around and does not seem to be influenced by cell count.

The benthic invertebrate population is dominated by Trichoptera and is large enough to serve as a major source of food for trout and forage fish. Areal variation in the species composition of the benthic invertebrate community seems to be due more to substrate preferences of the organisms than to areal variations in water quality. Biotic index values calculated from benthic invertebrate data and qualitative evaluation of the benthic invertebrate community indicate that the stream is relatively free of organic enrichment.

The trout population is low and represents only a small part of the total fish population, both in biomass and numbers. The wild trout population consists of brown trout. Brown trout are generally stocked annually, but most trout present in the fall are wild. Brook trout were stocked on two occasions--a wild population was established but subsequently disappeared.

The major environmental factors limiting trout population seem to be lack of sufficient cover, insufficient pool depth and volume, and sparse spawning areas. Food supply (invertebrates and forage fish) is sufficient to support a larger population, and critical water-quality factors (dissolved oxygen and temperature) present no significant problems. Fall trout population is highly dependent on spawning success the previous fall; when spawning success was poor, fall populations were extremely low even with supplemental stocking.

The floodwater-retention structure constructed during this study has affected the distribution of trout. Trout reproduced in the reach upstream from the structure before construction, but have apparently not done so since construction was completed. The structure may also impede the upstream migration of adult trout. 


\section{LITERATURE CITED}

Avery, E. L., 1978, The influence of chemical reclamation on a small brown trout stream in southwestern Wisconsin: Wisconsin Department of Natural Resources Technical Bulletin No. 110, $35 \mathrm{p}$.

Becker, G. C., 1966, Fishes of southwestern Wisconsin: Transactions of the Wisconsin Academy of Science, Arts, and Letters 55, p. 87-117.

Blum, J. L., 1956, The ecology of river algae: The Botanical Review, v. 22, no. 5, p. 291-341.

Brynildson, O. M., 1957, Fish populations and associated studies in Mt. Vernon and Black Earth Creeks: Wisconsin Conservation Department Job Plan 1-A, D.J. Project F-4-R-4, 9 p.

Brynildson, O. M., Hacker, V. A., and Klick, T. A., 1964, Brown trout--its life, history, ecology, and management: Wisconsin Conservation Department Publication 234, 15 p.

Brynildson, O. M., and Mason, J. W., 1975, Influence of organic pollution on the density and production of trout in a Wisconsin stream: Wisconsin Department of Natural Resources Technical Bulletin No. 81, $16 \mathrm{p}$.

Chutter, F. M., 1972, An empirical biotic index of the quality of water in South African streams and rivers: Water Research, v. 6, p. 19-30.

Crawford and Vernon County Soil and Water Conservation Districts, 1967, Watershed workshed work plan, Blackhawk-Kickapoo watershed: Crawford and Vernon County Soil and Water Conservation Districts, $32 \mathrm{p}$.

Dunst, R. C., 1970, The effect of streamflow upon brown trout reproduction in Black Earth Creek, Wisconsin: Madison, University of Wisconsin, M.S. thesis, $34 \mathrm{p}$.

Greene, C. W., 1935, The distribution of Wisconsin fishes: Wisconsin Conservation Commission, $235 \mathrm{p}$.

Greeson, P. E., Ehlke, T. A., Irwin, G. A., Lium, B. W., and Slack, K. V., 1977, Methods for collec- tion and analysis of aquaticbiological and microbiological samples: U.S. Geological Survey Techniques of Water Resources Investigations, Book 5, Chapter A4, 332 p.

Hilsenhoff, W. L., 1977, Use of arthropods to evaluate water quality of streams: Wisconsin Department of Natural Resources Technical Bulletin No. 100, 15 p.

Hunt, R. L., Brynildson, O. M., and McFadden, J. T., 1962, Effects of angling regulations on a wild brook trout fishery: Wisconsin Conservation Department Bulletin 26, 58 p.

Kammerer, P. A., Jr., and Sherrill, M. G., 1979, Hydrology and water quality in the Nederlo Creek basin, Wisconsin, before construction of two water-retention structures: U.S. Geological Survey Water-Resources Investigations 79-95, 34 p.

McFadden, J. T., 1961, A population study of brook trout, Salvelinus fontinalis: Wildlife Monograms 7, $73 \mathrm{p}$.

Weber, C. I., 1973, Percent developments in the measurement of the response of plankton and periphyton to changes in their environment, in Glass, G., ed., Bioassay techniques and environmental chemistry: Ann Arbor Science Publishers, Inc., p. 119-138.

White, R. J., 1964, Progress report on a study of the wild brown trout population and its habitat in Black Earth Creek, Wisconsin: Madison, University of Wisconsin, M.S. thesis, 109 p.

Whitton, B. A., ed., 1975, River ecology: University of California Press, 725 p.

Wilhm, J. L., and Dorris, T. C., 1968, Biological parameters for water quality criteria: Bioscience, v. 18, p. 477-481.

Wirth, T. L., and Mason, J. W., 1974, Environmental analysis of the Kickapoo River impoundment: Fish Population Investigations, University of Wisconsin Institute for Environmental Studies, p. 125-128. 